\title{
How much should we trust life satisfaction data? Evidence from the Life in Transition Survey
}

\author{
Elena Nikolova ${ }^{\mathrm{a}} \quad$ Peter Sanfey ${ }^{\mathrm{b}}$ \\ European Bank for Reconstruction and Development \\ One Exchange Square, London, EC2A 2JN, UK
}

\begin{abstract}
We analyse responses to two similar life satisfaction questions asked at different points in the same wave of a major cross-country household survey covering the transition region, Turkey and five Western European countries. We show that while the answers to the two questions are broadly consistent for most people, the responses for some groups differ significantly. Respondents of a lower socio-economic status and with a more favourable parental background show systematically higher levels of selfreported satisfaction in the later question. We also find evidence that responses to the later question are influenced by preceding questions on social capital. Our results have important implications for the design and length of household surveys that contain subjective questions.
\end{abstract}

Keywords: life satisfaction, measurement, transition region

JEL codes: D6, I31, P36

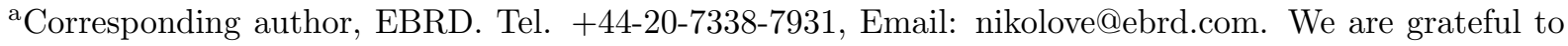
the Editor (Gérard Roland), an anonymous referee, Daniel Bennett, Ralph De Haas, Yannis Georgellis, Sergei Guriev, Milena Nikolova and seminar participants at EBRD, Kent Business School and the European Public Choice Society for helpful comments and suggestions, and to Milena Djourelova and Simon Hess for excellent research assistance. The views expressed in this paper are those of the authors only and not necessarily of the EBRD.

${ }^{\mathrm{b}}$ EBRD, Email: sanfeyp@ebrd.com. 


\section{Introduction}

In the past two decades, the study of life satisfaction, or "happiness," has become a thriving area of research in economics. There is now a firm body of evidence to support the view that surveys of well-being can yield meaningful and policy-relevant information about people's welfare. Increasingly, this research has spilled over into the policy arena, with institutions such as the OECD routinely constructing cross-country measures of happiness and producing guidelines on the appropriate methodology. ${ }^{1}$ But what happens when people are asked twice in the same interview about their well-being? Are the responses consistent or do they differ for some people, and if so, how? These questions, which have received little attention in the literature so far, are the focus of our paper.

Our analysis is based on the second round of the EBRD/World Bank Life in Transition Survey (LiTS II), a nationally representative household-level survey. LiTS II was carried out in late 2010 across 29 transition countries of central and eastern Europe and the former Soviet Union, Turkey and five western European countries (France, Germany, Italy, Sweden and the UK). A unique feature of this survey is that respondents are asked about their overall satisfaction with life at different points in the same interview, which allows us to study how intervening questions change the interviewee's initial life satisfaction answer. The first subjective well-being question, which asks respondents to agree or disagree with the statement "All things considered, I am satisfied with my life now," (on a five-point scale) appears relatively early in the interview. In contrast, the second question, phrased as follows: "All things considered, how satisfied or dissatisfied are you with your life as a whole these days? Please answer on a scale of 1 to 10, where 1 means completely dissatisfied and 10 means completely satisfied," is near the end of the questionnaire. While the questions are quite similar, there are differences when it comes to phrasing and scaling which may also drive the observed variation in responses.

Cojocaru and Diagne (2015) have looked at the consistency of the two measures and

\footnotetext{
${ }^{1}$ Life satisfaction is a key component of the OECD's "Better Life Initiative", described in http: //www.oecd.org/statistics/measuring-well-being-and-progress.htm. The United Nations produces an annual report on world happiness - see Helliwell et al. (2013).
} 
show that the answers are highly correlated at the country level. Although our individuallevel analysis is broadly in line with such a conclusion, we also find that for approximately $14 \%$ of respondents the answers to the two life satisfaction questions differ significantly. ${ }^{2}$ In our analysis, we test three specific hypotheses related to (1) the direction of the response switch (captured by the actual response difference) and (2) the precision of the two responses (proxied by the absolute value of the response difference):

- The responses may be affected by context and framing effects. Some of the questions and topics addressed between the first and second life satisfaction question may influence answers to the latter because they prompt respondents to evaluate good or bad aspects of their lives. ${ }^{3}$ We explore the extent to which answers to the second question appear to be influenced by socio-economic status, social capital, views on issues such as trust and corruption, and events from the past.

- Responses to life satisfaction questions may be significantly affected by an individual's mood, which can change markedly during the interview. The LiTS questionnaire is lengthy, with interviews typically lasting more than an hour. Therefore, an apparent drop in life satisfaction between the first and second question could be related to age and health, as older and less healthy people become tired and fed up as the interview progresses.

- In addition to leading to a downward bias in self-reported well-being in the second question, certain intervening questions and individual characteristics may affect the recall of previous information and thus the measurement error in responses.

We find that several groups of people report a decrease in life satisfaction in the second question. Higher education (both individual and parental), income and social capital have a positive effect on responses to the second well-being question, though favourable opinions

\footnotetext{
${ }^{2}$ We explain below what we mean by a "significant" difference between the two responses.

${ }^{3}$ The importance of context and framing effects has been analysed extensively in the psychology literature. See Diener et al. (2013) who point to the relevance of "chronically accessible information, which is information that readily comes to mind when people think of their lives" as a determinant of life satisfaction scores.
} 
about institutions are either insignificant or, surprisingly, seem to bias life satisfaction scores downward in the second question. Those aged 63 and above and people who report themselves to be less healthy (on a 1-5 scale) appear on average to experience a drop in life satisfaction during the interview, though these effects are less robust. Lastly, our results suggest that response precision is positively associated with individual socioeconomic status (captured by controls for education, income and employment status).

Of course, the "gold-standard" approach would be to use two identical life satisfaction questions whose position is randomly assigned in the survey. This is an important limitation of our work. Unfortunately, a research design of this type may be difficult and expensive to carry out in a large cross-country survey such as the LiTS. In the absence of such an approach, we believe that the research strategy adopted in this paper provides an important methodological contribution.

Since our regressions are based on cross-sectional data, a potential concern is that the results may be driven by unobservable individual traits (Ferrer-i Carbonell and Frijters, 2004). We adopt four complementary approaches to deal with such issues. First, by construction, our dependent variable (the response difference to the two life satisfaction question) eliminates individual-specific effects, which may otherwise have contaminated the estimates. Second, we control for a rich set of observable individual characteristics, ranging from health and marital status to political party membership. Third, we also include country dummies (in the baseline specification) as well as dummies at the levels of sub-national administrative regions and even primary sampling units (PSUs) (in the robustness checks). By comparing similar individuals within very narrow geographical areas, our empirical analysis makes it less likely that the observed effects are driven by fixed sub-national differences such as geography or culture. Finally, it is reassuring that our results survive multiple robustness checks, such as the inclusion of interviewer fixed effects or alternative estimation techniques. Although we cannot eliminate all sources of bias in our cross-sectional data, our multi-pronged, micro-level approach makes us more confident that the relationships which we uncover are likely to be causal. 
We contribute to the literature in several ways. First, the unique research setup implemented in this paper provides us with the rare opportunity to identify the biases associated with data on subjective well-being. More substantively, we complement a small but increasingly important literature which looks at how answers to life satisfaction questions vary with various survey characteristics ranging from order effects and the type of preceding questions to the accessibility and motivation of respondents. ${ }^{4}$ While this work is largely based on surveys from single advanced countries, we show that similar concerns about life satisfaction responses may be applicable in a broader cross-section. In fact, the magnitude as well as source of biases which we uncover are remarkably similar when we compare the transition region with the six non-transition countries in our sample (Turkey, Germany, France, Italy, Sweden and the UK). ${ }^{5}$

Finally, our results have important implications for studies on the economics of happiness. The finding that answers to two different questions on subjective well-being are broadly consistent for most people is comforting as it suggests that such data are not unduly driven by random noise and can in fact capture meaningful variation in life satisfaction. Similarly, our findings that reported happiness changes little once respondents are asked a battery of sensitive political questions are encouraging and stand in contrast to other work on the US, such as Deaton (2012). However, since life satisfaction responses are subject to nontrivial bias for respondents of lower socio-economic status (and sometimes those who are older and less healthy), researchers should pay particular attention to these groups when conducting econometric analyses. More generally, our results show that a re-think may be needed regarding the design of future rounds of the LiTS (and possibly other major household surveys that include questions on subjective well-being), which we discuss in more detail in the conclusion.

\footnotetext{
${ }^{4}$ We review these contributions in more detail in the following section.

${ }^{5}$ Such a comparison involves the caveat that the transition sample is much bigger than the non-transition one.
} 


\section{Previous literature}

While many economists have studied the determinants of life satisfaction, the economics literature examining issues of measurement has been slower to develop. ${ }^{6}$ Nevertheless, psychology and marketing researchers have long recognised the importance of tackling response biases in surveys, and economists are increasingly drawing on these findings and insights in their research on subjective well-being. ${ }^{7}$ We build on several recent influential contributions, summarised below, that seek to understand the possible biases involved in subjective wellbeing responses. ${ }^{8}$ To the best of our knowledge, however, there are no prior studies seeking to examine how reported life satisfaction may vary within the same interview in a large cross-country survey focused on the transition region such as the LiTS.

Comparing daily data from the Gallup World Poll in the US, Deaton (2012) finds that life satisfaction measures are extremely dependent on question ordering. He exploits the fact that in early 2009, Gallup randomly split the sample of respondents, with half of interviewees being asked questions on political preferences prior to the life satisfaction question, while for the other half of respondents the life satisfaction question came first. It turns out that the former setup reduces substantially self-reported well-being, and that the magnitude of this reduction is in fact much higher than the perceived impact of the Great Recession. This should not come as a particular surprise, since in the psychology literature, it has long been recognised that self-reported answers on attitudes and feelings can be affected by context and ordering of questions (Schimmack and Oishi, 2005; Schwarz, 1999).

In contrast, Krueger and Schkade (2008) find that two different measures of life satisfaction (a standard survey question and data on affective experience collected using the Day Reconstruction Method two weeks after the interview) have a reasonably high serial correlation (0.6) for a sample of 229 women in the US. Although this figure is lower than the

\footnotetext{
${ }^{6}$ See Frey and Stutzer (2010), Layard (2005) and Powdthavee (2010) for useful surveys of the literature on the economics of happiness. There is also a small but growing literature on life satisfaction in the transition region (which comprises the majority of our sample), some of which has tried to explain the relatively low levels of happiness compared with other parts of the world (see Dabalen and Paul (2011), Djankov et al. (2015), Guriev and Zhuravskaya (2009), Kornai (2006), Senik (2009) and Sanfey and Teksoz (2007)).

${ }^{\top}$ Podsakoff et al. (2003) is an authoritative survey of method biases in behavioural research.

${ }^{8}$ See Kahneman and Krueger (2006) for an earlier survey of this literature.
} 
reliability ratios for objective measures such as education or income, the authors suggest that it is probably sufficient to yield informative measures in large samples. ${ }^{9}$

Life satisfaction data may be subject to additional biases. Conti and Pudney (2011) show that a seemingly minor change in the job satisfaction question in the British Household Panel Survey (BHPS) - the switch from partial use of textual labels (in addition to numerical labels) as anchors for the response scale (in the 1991 survey) to their full use (in the 1992 survey) - leads to large inconsistencies in the distribution of responses. In particular, women are more likely to pick responses accompanied by textual labels. The authors find that survey mode administration (face-to-face as compared to self-administered) and context (presence of partner and children) also matter, more so for women than for men. ${ }^{10}$ Interviewer characteristics (including gender and interviewing experience) may also sway life satisfaction responses (Chadi, 2013; Kassenboehmer and Haisken-DeNew, 2012).

Yet another strand of the literature examines to what extent subjective well-being responses vary with interviewees' accessibility and motivation. Using the reported number of call attempts in the University of Michigan's Survey of Consumers, Heffetz and Rabin (2013) show that life-satisfaction levels are higher among easy-to-reach women (as compared to easy-to-reach men), but that hard-to-reach men are happier than hard-to-reach women. The authors warn that these unexpected effects of sample selection are likely to be even more severe when fewer contact attempts are made. In a similar vein, Chadi (2014) shows that in the German Socio-Economic Panel Study, respondents with a higher number of interviewer contacts report lower levels of life satisfaction, possibly because such respondents are less motivated to go through with the interview. ${ }^{11}$

\footnotetext{
${ }^{9}$ See also Studer (2012) who utilises a randomised design in a Dutch internet panel survey to argue that a continuous life satisfaction scale provides more discriminating power than a discrete one.

${ }^{1 C}$ Dolan and Kavetsos (2012) find that in the 2011 Annual Population Survey in the UK, respondents who are interviewed over the phone are consistently happier than those in face-to-face interviews, and that the determinants of subjective well-being depend on survey mode. Using multiple waves of the Eurobarometer data, Kavetsos et al. (2014) find that life satisfaction depends on the day and month of the interview (but not time of day), and that SWB is significantly reduced when others are present.

${ }^{11}$ In the case of the LiTS, if a selected respondent was unavailable, enumerators conducted up to three follow-up visits, though unfortunately an exact breakdown for each respondent is not available in our data.
} 


\section{Data description}

\subsection{The Life in Transition Survey}

Our analysis is based on the second round of the Life in Transition Survey, which covers virtually all transition countries in central and eastern Europe and the former Soviet Union (as well as Mongolia and Turkey), except Turkmenistan. ${ }^{12}$ Unlike the first round of the survey, LiTS II also includes five western European comparator countries. All of these countries are included in the analysis below, although as we discuss in the robustness section, results are very similar if we only restrict our sample to countries in the transition region. ${ }^{13}$

Respondents were drawn randomly, using a two-stage sampling method with primary and secondary sampling units. The Primary Sampling Units (PSU) are electoral districts, polling station territories, census enumeration districts or geo-administrative divisions, while Secondary Sampling Units are households. Each country has a minimum of 50 PSUs with each PSU containing around 20 households (for a total of approximately 1,000 observations), with the exception of Russia, Ukraine, Uzbekistan, Serbia and Poland, where 75 PSUs containing around 20 households each were drawn (for a total of approximately 1,500 observations). The head of the household or another knowledgeable household member answered the Household Roster and questions about housing and expenses, while all other modules - including the two different life satisfaction question - were answered by a randomly drawn adult (over 18 years of age) from the household in a face-to-face interview with no substitutions possible. ${ }^{14}$

In Section 3, interviewees are asked a series of questions about attitudes and values. The section opens with the respondent being asked: "To what extent do you agree with the following statements?" One of the statements is: "All things considered, I am satisfied with my

\footnotetext{
${ }^{12}$ Further details on the Life in Transition Survey, and the full data set, can be accessed at http://www. ebrd.com/what-we-do/economic-research-and-data/data/lits.html

${ }^{13}$ Two recent papers use LiTS to study the drivers of happiness in the transition region. Cojocaru (2014) investigates the link between inequality and well-being, while Popova (2014) argues that religion can serve as an insurance against aggregate shocks to life satisfaction, such as privatization and enterprise restructuring.

${ }^{14}$ The other modules are: Attitudes and Values; Climate Change; Labour, Education and Entrepreneurial Activity; Governance, Miscellaneous Questions, and Impact of the Crisis (the latter also answered by the household head).
} 
life now." The response could be one of the following: strongly disagree, disagree, neither disagree nor agree, agree, and strongly agree. The answers can be converted to a numerical 1-5 scale, where 1 represents "strongly disagree" and 5 "strongly agree." Section 7 is entitled "Miscellaneous questions" and covers various aspects of the interviewee's background and activities. The final question in this section is: "All things considered, how satisfied or dissatisfied are you with your life as a whole these days? Please answer on a scale of 1 to 10, where 1 means completely dissatisfied and 10 means completely satisfied." Showcards were used to present the answer options to the respondent for both questions. ${ }^{15}$ The LiTS also records information on the duration, date and time of the interview, but inconsistent enforcement means that these data are less reliable (in some cases, our sample also drops significantly). We also obtained information on the identity of the interviewer (captured by an interviewer dummy variable) for all countries except Italy. The results from specifications which control for interview duration and interviewer identity (presented in the online Appendix) are consistent with our baseline findings below.

Figures 1 and 2 show how the scores in these two questions are distributed. The modal response to the first question is "agree" (score of 4), and the simple average of all responses is 3.18. The modal response to the second question is just 5 (on the 1 to 10 scale) with a simple average of 5.52 .

\footnotetext{
15 "Do not know" and "not applicable" (first question) and "not stated" (second question) are also allowed, but not shown on the cards presented to respondents. However, due to the small number of respondents who picked these options (732 for the first question and 8 for the second question), the answers are disregarded in the paper.
} 


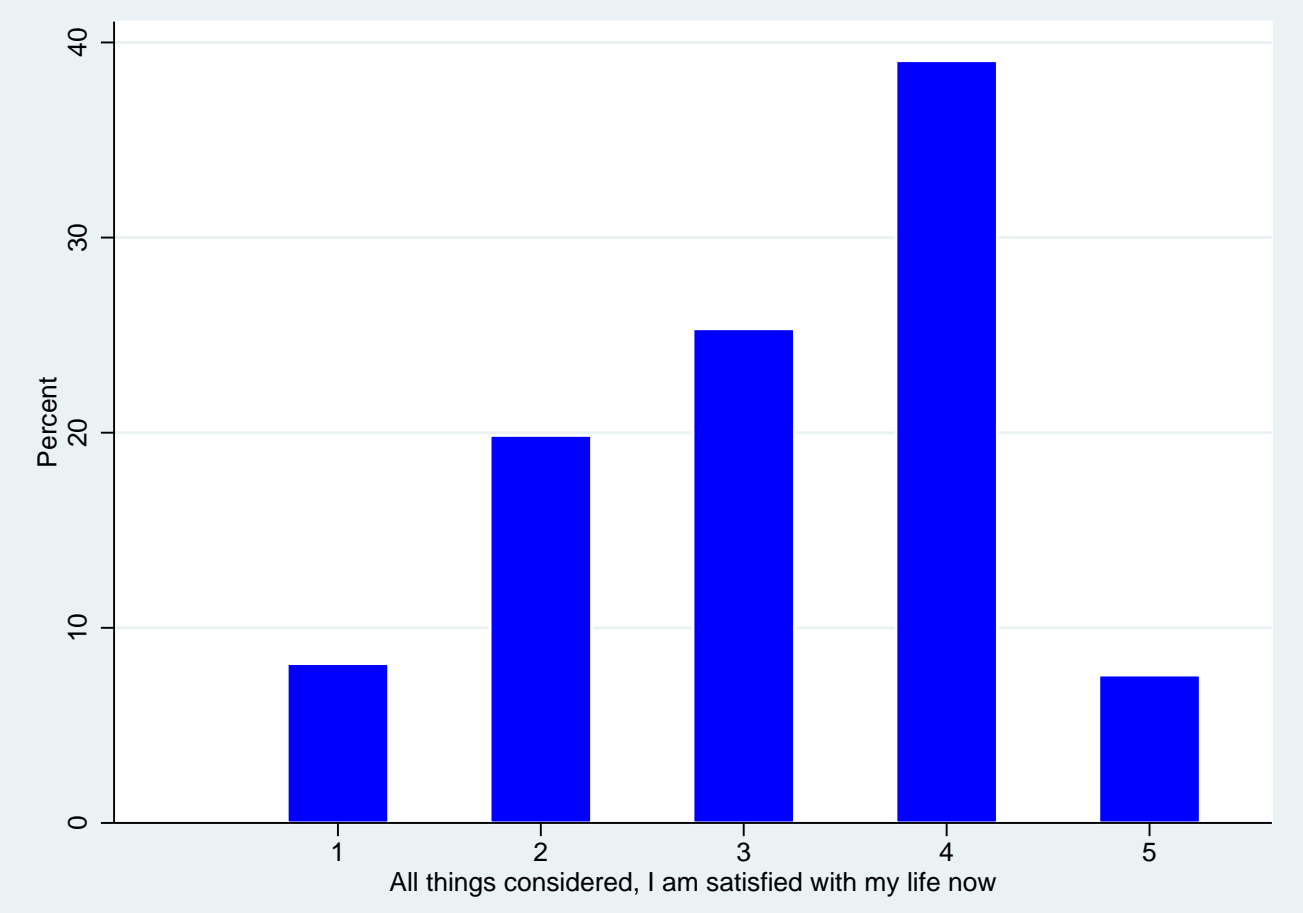

Figure 1: Distribution of responses - first life satisfaction question

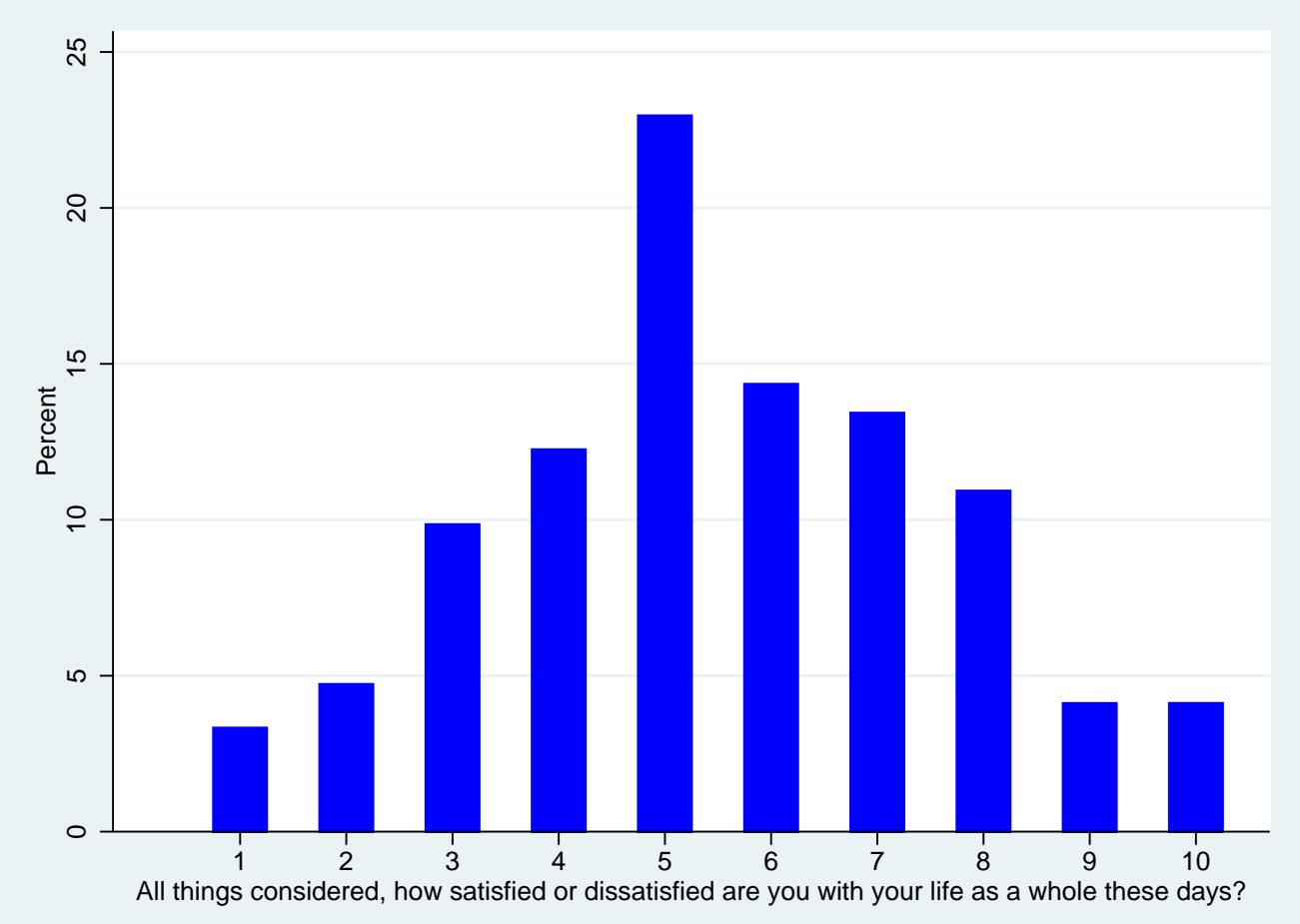

Figure 2: Distribution of responses - second life satisfaction question 


\subsection{Calculating the difference in life satisfaction responses}

To explore this further, we look at how the responses differ at the individual level. We construct a nine-point index, $D_{1}$ as follows: define the first satisfaction question as $Q_{1}$ and the second one as $Q_{2}$. Then:

$$
D_{1}=S_{2}-S_{1}
$$

where $S_{2}=1$ if the answer to $Q_{2}=1$ or $2, S_{2}=2$ if the answer is 3 or $4, \ldots, S_{2}=5$ if the answer $=9$ or 10 , and $S_{1}=[1, \ldots, 5]$, as described above. ${ }^{16} D_{1}$ is therefore on a 9point scale, ranging from -4 to 4 . That is, someone who "strongly agrees" that, all things considered, he/she is satisfied with life now but scores the second question at 1 or 2 would have a $D_{1}$ score of -4 , whereas "strongly disagree" on the first question, combined with 9 or 10 on the second question would be a $D_{1}$ score of 4 . Figure 3 shows the distribution of $D_{1}$ across the entire sample. Not surprisingly, the modal score is 0 (with a mean of -0.15 and a standard deviation of 1.07), suggesting a relatively high degree of comparability across the two measures of life satisfaction, consistent with the cross-country findings of Cojocaru and Diagne (2015). However, $14.39 \%$ of the sample show a significant deviation in their answers, as captured by scores of 2 and above or -2 and below. The next section tries to explain the variation across individuals by testing econometrically the hypotheses mentioned in the introduction.

\footnotetext{
${ }^{16}$ Note that in the robustness section we experiment with a variety of alternative coding approaches, including a categorical variable and a standardized difference, which yield very similar results.
} 


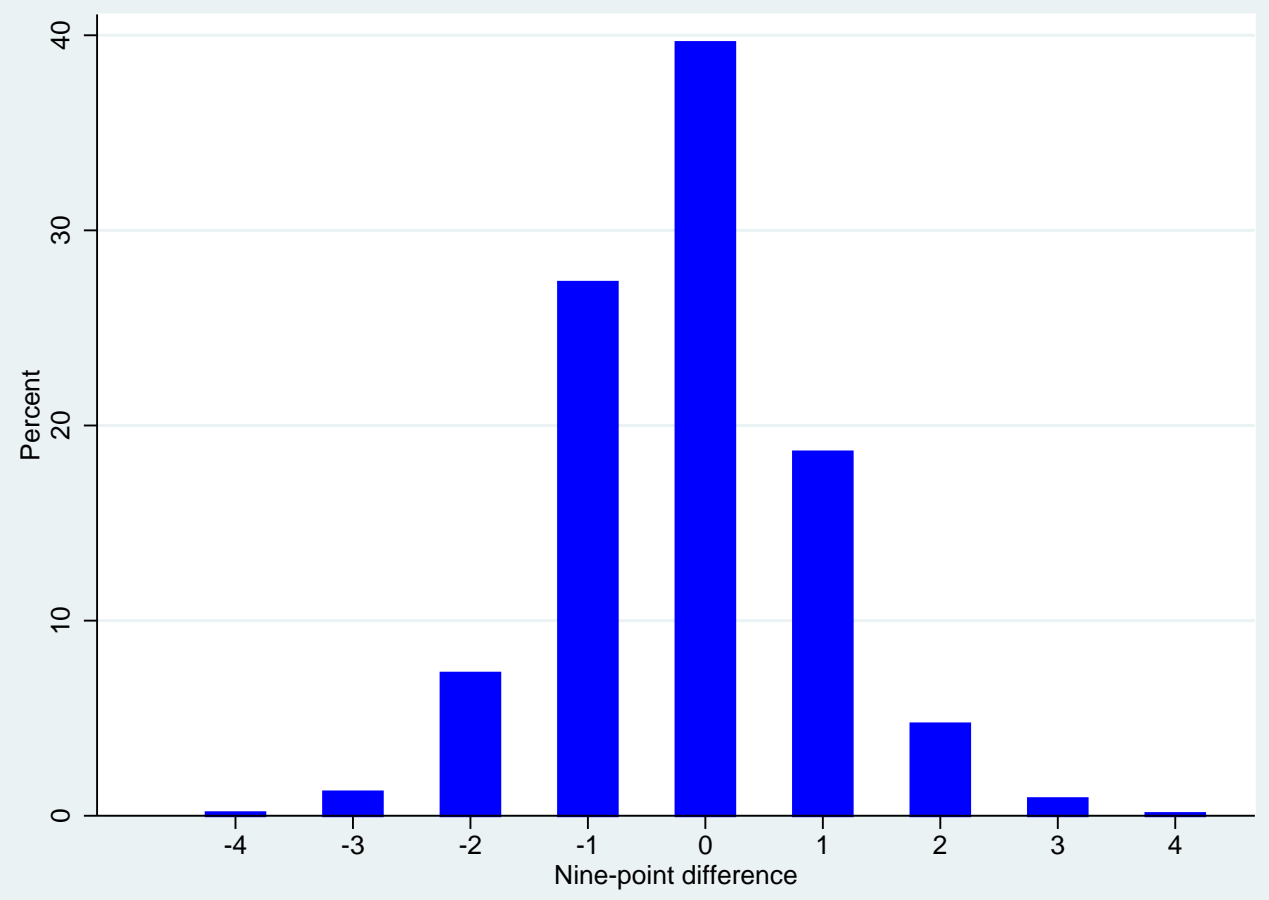

Figure 3: Histogram of the nine-point difference in responses 


\section{Econometric analysis}

We estimate the following equation:

$$
D_{1 i k}=\alpha_{i k}+\beta_{1} \text { AgeDummies }_{i k}+\beta_{2} \text { Health }_{i k}+\beta_{3} \text { MaritalStatus }_{i k}+\boldsymbol{X}_{\boldsymbol{i k}} \beta_{4}+\gamma_{k}+\epsilon_{i k},
$$

where for each individual $i$ in country $k$ Age Dummies Dik $_{\text {in }}$ a set of age dummies (with the cohort aged 42-52 the omitted category), Health $h_{i k}$ is the respondent's self-assessed health on a scale of 1 (very bad) to 5 (very good), and Marital Status $i k$ is a dummy variable taking the value of 1 if the respondent is married and 0 otherwise. $\boldsymbol{X}_{\boldsymbol{i k}}$ is a matrix of additional controls which vary across specifications and include the following broad categories: (1) individual socio-economic characteristics (level of education, income and whether the individual was employed in the past 12 months); (2) parental background (father's education and whether the respondent or his parents/grandparents were injured, killed or displaced during World War II); (3) perceptions of institutions (opinion about corruption, trust in institutions, the degree to which the respondent believes effective institutions exist in the country, and support for income equality); and (4) social capital (how often the respondent meets up with friends, whether he/she is a member of a political party, and whether he/she is an active member of various social organisations). $\gamma_{k}$ is a country fixed effect, and standard errors are clustered at the country level. Survey weights, which ensure that the data are representative at the country level, are used in all specifications. More information on the variables is available in the online Appendix.

We include age and health on the grounds that older and less healthy people may find their mood, and hence their feeling of life satisfaction, dropping during the lengthy interview. Therefore, we test if $\beta_{1}<0$ (for individuals in the highest age categories) and $\beta_{2}>0$. In the happiness literature marital status is usually associated with higher levels of life satisfaction, and inclusion of this variable shortly before the second life satisfaction question may temporarily raise the mood of those who are married (implying that $\beta_{3}>0$ ).

Similarly, the literature shows that life satisfaction is positively correlated with income, 
education and employment. Being reminded of one's status on these matters before the second life satisfaction question may give a boost to the index for those who score well on these counts, and conversely may temporarily depress those who are uneducated, with low income or unemployed. Respondents with a more favourable parental background, better perceptions of institutions, and more social capital should also be more likely to report higher levels of life satisfaction in the second question as they are reminded about these aspects of their lives, so we expect that $\beta_{4}>0$. Country dummies capture fixed characteristics like geography or historical factors.

Since our data set is not an individual panel, an important issue relates to the bias associated with unobservable characteristics, either at the individual, country or locality level. We believe that such a critique is less convincing in our case for several reasons. First, we calculate our dependent variable using the response difference between the second and first life satisfaction question, and this difference does not depend on fixed individual characteristics. Moreover, we show that our estimates are robust to including a wide range of observable characteristics, such as age and marital status, social capital and interviewer characteristics. Crucially, our specifications include either country dummies (in the baseline specification) or dummies at the levels of sub-national administrative regions and even primary sampling units (PSUs) (in the robustness checks). We thus compare similar individuals within narrow geographical units (such as villages or city neighbourhoods when we look at within-PSU variation), which makes it less likely that our results are driven by spurious correlations.

Table 1 empirically tests the three hypotheses on which we elaborated in the introduction. Column (1) shows that being in the highest age group (age 63 and above) has a negative and statistically significant impact on the difference index, consistent with the notion that subjective well-being dips during the interview among the elderly. On average, older respondents report levels of happiness in the second life satisfaction question which are around 0.09 points lower, though this magnitude drops slightly when we introduce additional covariates in the other columns. While such an effect may appear small, one must keep in mind that the dependent variable is distributed with a very small mean $(-0.15)$ but a relatively large 
standard deviation (1.07). Similarly, health status is also significantly and positively correlated with the difference index. However, the coefficient on being married, while positive, is imprecisely estimated.

In the remaining columns of Table 1, we present the results of several specifications with framing variables, where different groups of variables are added separately to the baseline model of column 1. In column 2, we add the respondent's level of education (on a scale of 1 to 6 , with 1 being no education and 6 being Master's and Ph.D.-level education), income (as measured by self-assessment of one's position on a 10-step income ladder) and a dummy variable for employment in the past 12 months. Both education and income are positive and statistically significant. A one-unit increase in education (for instance, from no education to primary education, or from Bachelor-level education to Master's/Ph.D) makes a respondent nearly 0.03 points happier in the second question, while the effect of a one-standard deviation rise in income is 0.042 points.

These findings point to possible framing effects of questions about socio-economic status. As Diener et al. (2013) have argued, responses to questions on life satisfaction can be influenced by the accessibility of temporary information, which in turn is affected by preceding questions. At the same time, one should be cautious about this interpretation because there is a significant gap in the questionnaire between these socio-economic questions and the second life satisfaction question. It is worth pointing out that the positive impacts seem to outweigh a possible countervailing effect whereby richer and more educated people have a higher opportunity cost of time and hence may become impatient and dissatisfied by the time of the second life satisfaction question.

Column 3 instead adds to the baseline specification two variables that relate (largely) to the respondent's parents and grandparents. One is the level of the father's education (measured in years of full-time education), which has a positive impact on the difference index, and suggests that those whose fathers have on average four more years of education (roughly the difference between high-school and university) report happiness scores in the second question that are nearly 0.06 points higher. The other variable is a dummy for whether 
the respondent, or any of his/her parents or grandparents, were killed, injured or forced to move during the second world war. Because the latter question is asked just before the second life satisfaction question, one might expect an impact on responses. It turns out that there is either no impact, or even a positive one (when only displacement is considered in unreported results). While this may be surprising, it has been noted in the psychology literature that the recall of negative events in the distant past (as opposed to more recent ones) can result in higher life satisfaction than for those recalling positive events. ${ }^{17}$

In column 4 we add several variables relating to attitudes and beliefs about trust, corruption and the effectiveness of institutions. Although our expectation was that a negative view on these issues - for example, a belief that corruption is widespread - would be associated with a drop in the difference index, the results are either insignificant or go the opposite way. This is a puzzle that merits further investigation, but one possibility could be that more trustworthy people may be more likely to agree with the first life satisfaction question and reverse their response afterward. Interestingly, however, there is a statistically significant and negative relationship between the dummy variable capturing whether the respondent supports income equality and the difference in life satisfaction, in the magnitude of around 0.07 points.

In column 5 we introduce several social capital variables: whether the person meets regularly with friends (on a scale of 1 (never) to 5 (most days)), and participates in a political party (a dummy variable) or different organisations (ranging from 0 to 9 to capture all the organisations in which the respondent may be involved). In this case, we find supportive evidence for framing effects for two out of the three variables. Those who say they rarely or never meet up with friends tend to record lower life satisfaction scores in the second question, while those who are active in various organisations record a boost to their numerical life satisfaction. Membership in a political party is not significant. It is also possible that respondents with social capital find the interview more enjoyable, prompting them to give a higher answer to the second life satisfaction question.

\footnotetext{
${ }^{17}$ See Schwarz (1999).
} 
Lastly, column 6 reports the results of an all-encompassing equation, including simultaneously all variables from the previous columns. The main conclusions for income, education, father's education and the social capital variables remain broadly valid, but some other results, including those relating to health and age lose statistical significance. This is not surprising, since older and less healthy respondents are likely to be of lower socio-economic status. $^{18}$

\footnotetext{
${ }^{18}$ Country dummies are included in all regressions but their coefficients are not reported. It is interesting to note that in some central Asian countries, the coefficients on the country dummies are significantly negative relative to the reference country (Russia). This suggests that responses to a life satisfaction question with an agree/disagree response scale in more autocratic countries tend to be systematically higher than answers on a numerical scale. However, the link between autocracy and country dummy scores does not emerge clearly from the full sample, as country dummies also capture additional fixed or slow-moving characteristics such as climate, geography or culture.
} 


\begin{tabular}{|c|c|c|c|}
\hline & $\begin{array}{c}(1) \\
\text { nine-point difference }\end{array}$ & $\begin{array}{c}(2) \\
\text { nine-point difference }\end{array}$ & $\begin{array}{c}(3) \\
\text { nine-point difference }\end{array}$ \\
\hline \multicolumn{4}{|l|}{$\underline{\text { baseline }}$} \\
\hline health & $\begin{array}{l}0.0379^{* * *} \\
(0.0111)\end{array}$ & $\begin{array}{r}0.0224^{*} \\
(0.0117)\end{array}$ & $\begin{array}{c}0.0231^{*} \\
(0.0122)\end{array}$ \\
\hline married & $\begin{array}{c}0.0162 \\
(0.0144)\end{array}$ & $\begin{array}{c}0.00764 \\
(0.0144)\end{array}$ & $\begin{array}{c}0.0109 \\
(0.0163)\end{array}$ \\
\hline Age $18-22$ & $\begin{array}{c}0.0163 \\
(0.0326)\end{array}$ & $\begin{array}{c}0.0191 \\
(0.0337)\end{array}$ & $\begin{array}{r}0.00859 \\
(0.0385)\end{array}$ \\
\hline Age 23-32 & $\begin{array}{c}-0.00759 \\
(0.0225)\end{array}$ & $\begin{array}{c}-0.0171 \\
(0.0237)\end{array}$ & $\begin{array}{c}-0.0441 \\
(0.0265)\end{array}$ \\
\hline Age $33-42$ & $\begin{array}{r}0.00501 \\
(0.0158)\end{array}$ & $\begin{array}{r}0.00836 \\
(0.0161)\end{array}$ & $\begin{array}{c}-0.00558 \\
(0.0188)\end{array}$ \\
\hline Age $53-62$ & $\begin{array}{r}0.00141 \\
(0.0196)\end{array}$ & $\begin{array}{r}0.00859 \\
(0.0201)\end{array}$ & $\begin{array}{c}0.0167 \\
(0.0253)\end{array}$ \\
\hline Age 63- & $\begin{array}{l}-0.0937^{* * *} \\
(0.0213)\end{array}$ & $\begin{array}{l}-0.0657^{* * *} \\
(0.0214)\end{array}$ & $\begin{array}{l}-0.0584^{* *} \\
(0.0258)\end{array}$ \\
\hline \multicolumn{4}{|l|}{ individual SES } \\
\hline education & & $\begin{array}{c}0.0253^{* * *} \\
(0.00609)\end{array}$ & \\
\hline income & & $\begin{array}{l}0.0254^{* * *} \\
(0.00771)\end{array}$ & \\
\hline employed & & $\begin{array}{c}0.00670 \\
(0.0196)\end{array}$ & \\
\hline \multicolumn{4}{|l|}{ parental background } \\
\hline father's education & & & $\begin{array}{l}0.0141^{* * *} \\
(0.00263)\end{array}$ \\
\hline affected by war & & & $\begin{array}{c}0.0128 \\
(0.0204)\end{array}$ \\
\hline Country dummies & $\checkmark$ & $\checkmark$ & $\checkmark$ \\
\hline $\begin{array}{l}\text { Observations } \\
R^{2}\end{array}$ & $\begin{array}{r}37792 \\
0.0428\end{array}$ & $\begin{array}{l}36259 \\
0.0465\end{array}$ & $\begin{array}{r}26045 \\
0.0481\end{array}$ \\
\hline
\end{tabular}

Notes: Dependent variable is the nine-point difference between the second life satisfaction question and the first life satisfaction question. OLS - Coefficients are reported. Standard errors are clustered at the country level. Significance levels: ${ }^{*} p<0.1,{ }^{* *} p<0.05$, *** $p<0.01$.

Table 1: Determinants of difference in answers to the two life satisfaction questions 


\begin{tabular}{|c|c|c|c|}
\hline & $\begin{array}{c}(4) \\
\text { nine-point difference }\end{array}$ & $\begin{array}{c}(5) \\
\text { nine-point difference }\end{array}$ & $\begin{array}{c}(6) \\
\text { nine-point difference }\end{array}$ \\
\hline \multicolumn{4}{|l|}{$\underline{\text { baseline }}$} \\
\hline health & $\begin{array}{l}0.0515^{* * *} \\
(0.00961)\end{array}$ & $\begin{array}{l}0.0359^{* * *} \\
(0.0108)\end{array}$ & $\begin{array}{c}0.0204 \\
(0.0124)\end{array}$ \\
\hline married & $\begin{array}{l}0.0289^{* *} \\
(0.0133)\end{array}$ & $\begin{array}{c}0.0167 \\
(0.0147)\end{array}$ & $\begin{array}{r}0.00897 \\
(0.0166)\end{array}$ \\
\hline Age $18-22$ & $\begin{array}{c}0.0240 \\
(0.0315)\end{array}$ & $\begin{array}{c}0.00679 \\
(0.0320)\end{array}$ & $\begin{array}{c}-0.00325 \\
(0.0461)\end{array}$ \\
\hline Age $23-32$ & $\begin{array}{l}-0.0126 \\
(0.0224)\end{array}$ & $\begin{array}{c}-0.0121 \\
(0.0221)\end{array}$ & $\begin{array}{c}-0.0396 \\
(0.0257)\end{array}$ \\
\hline Age $33-42$ & $\begin{array}{r}0.00282 \\
(0.0177)\end{array}$ & $\begin{array}{r}0.00542 \\
(0.0157)\end{array}$ & $\begin{array}{c}-0.00145 \\
(0.0183)\end{array}$ \\
\hline Age 53-62 & $\begin{array}{c}-0.00403 \\
(0.0226)\end{array}$ & $\begin{array}{c}-0.000264 \\
(0.0194)\end{array}$ & $\begin{array}{c}0.0203 \\
(0.0289)\end{array}$ \\
\hline Age 63- & $\begin{array}{c}-0.0620^{* *} \\
(0.0263)\end{array}$ & $\begin{array}{l}-0.0916^{* * *} \\
(0.0218)\end{array}$ & $\begin{array}{c}-0.00349 \\
(0.0269)\end{array}$ \\
\hline \multicolumn{4}{|l|}{ individual SES } \\
\hline education & & & $\begin{array}{c}0.0111^{*} \\
(0.00627)\end{array}$ \\
\hline income & & & $\begin{array}{l}0.0306^{* * *} \\
(0.00846)\end{array}$ \\
\hline employed & & & $\begin{array}{c}0.00776 \\
(0.0228)\end{array}$ \\
\hline \multicolumn{4}{|l|}{$\underline{\text { parental background }}$} \\
\hline father's education & & & $\begin{array}{l}0.00911^{* * *} \\
(0.00277)\end{array}$ \\
\hline affected by war & & & $\begin{array}{c}0.0271 \\
(0.0226)\end{array}$ \\
\hline \multicolumn{4}{|l|}{ perception of institutions } \\
\hline trust institutions & $\begin{array}{l}-0.0756^{* * *} \\
(0.0153)\end{array}$ & & $\begin{array}{l}-0.0889^{* * *} \\
(0.0181)\end{array}$ \\
\hline effective institutions exist & $\begin{array}{c}-0.102^{* * *} \\
(0.0179)\end{array}$ & & $\begin{array}{l}-0.0949^{* * *} \\
(0.0211)\end{array}$ \\
\hline political liberties exist & $\begin{array}{c}0.00966 \\
(0.0200)\end{array}$ & & $\begin{array}{c}0.0112 \\
(0.0227)\end{array}$ \\
\hline corruption exists & $\begin{array}{c}0.00136 \\
(0.00196)\end{array}$ & & $\begin{array}{c}0.00138 \\
(0.00199)\end{array}$ \\
\hline incomes should be more equal & $\begin{array}{l}-0.0662^{* * *} \\
(0.0194)\end{array}$ & & $\begin{array}{l}-0.0610^{* * *} \\
(0.0209)\end{array}$ \\
\hline \multicolumn{4}{|l|}{$\underline{\text { social capital }}$} \\
\hline meet up with friends & & $\begin{array}{r}0.0174^{* *} \\
(0.00766)\end{array}$ & $\begin{array}{c}0.0260^{* *} \\
(0.0103)\end{array}$ \\
\hline member of a political party & & $\begin{array}{c}-0.0502 \\
(0.0332)\end{array}$ & $\begin{array}{c}-0.0691 \\
(0.0432)\end{array}$ \\
\hline active member of organizations & & $\begin{array}{l}0.0256^{* * *} \\
(0.00932)\end{array}$ & $\begin{array}{c}0.0184 \\
(0.0111)\end{array}$ \\
\hline Country dummies & $\checkmark$ & $\checkmark$ & $\checkmark$ \\
\hline Observations & 26945 & 37124 & 18939 \\
\hline$R^{2}$ & 0.0567 & 0.0435 & 0.0670 \\
\hline
\end{tabular}

Notes: Dependent variable is the nine-point difference between the second life satisfaction question and the first life satisfaction question. OLS - Coefficients are reported. Standard errors are clustered at the country level. Significance levels: ${ }^{*} p<0.1,{ }^{* *} p<0.05,{ }^{* * *} p<0.01$.

\section{Table 1 (continued)}


To test to what extent intervening questions and individual characteristics affect the recall of information and measurement error in life satisfaction responses, we next run a version of our estimating equation in which we simply take the absolute value of the difference as a dependent variable, thus ignoring whether answers to the second satisfaction question are higher or lower than the first one (see Figure A1 in the online Appendix for a snapshot of the distribution of this variable). The results, which are presented in Table 2 , show that individuals with lower socio-economic status (captured by education, income and employment dummy) are less likely to give consistent responses. Using the point estimates in column 2, being employed increases response precision by around 0.03 points $(3.8 \%$ relative to the mean of the dependent variable), while the effect of a one-step increase in perceived income (on a ten-step income ladder) is around 0.02 points $(2.4 \%$ relative to the mean of the dependent variable). ${ }^{19}$ This suggests that data on well-being for uneducated, low-income or unemployed groups may be subject to more noise, implying the need for robustness checks on these groups in life satisfaction studies. Controls for father's education, perceptions of institutions and social capital are not significant and do not change these results, hence they are omitted from the table to conserve space.

\footnotetext{
${ }^{19}$ The absolute difference has a mean of 0.77 with a standard deviation of 0.76 .
} 


\begin{tabular}{|c|c|c|}
\hline & $\begin{array}{c}(1) \\
\text { absolute diff. }\end{array}$ & $\begin{array}{c}(2) \\
\text { absolute diff. }\end{array}$ \\
\hline \multicolumn{3}{|l|}{ baseline } \\
\hline health & $\begin{array}{c}-0.00678 \\
(0.00732)\end{array}$ & $\begin{array}{c}-0.0104 \\
(0.00987)\end{array}$ \\
\hline married & $\begin{array}{r}0.00147 \\
(0.0110)\end{array}$ & $\begin{array}{r}0.00247 \\
(0.0162)\end{array}$ \\
\hline Age $18-22$ & $\begin{array}{c}-0.0195 \\
(0.0137)\end{array}$ & $\begin{array}{c}-0.0470^{* *} \\
(0.0217)\end{array}$ \\
\hline Age 23-32 & $\begin{array}{r}-0.00517 \\
(0.0110)\end{array}$ & $\begin{array}{r}-0.00817 \\
(0.0185)\end{array}$ \\
\hline Age $33-42$ & $\begin{array}{c}-0.0167 \\
(0.0108)\end{array}$ & $\begin{array}{c}-0.0132 \\
(0.0142)\end{array}$ \\
\hline Age $53-62$ & $\begin{array}{r}-0.0230^{*} \\
(0.0127)\end{array}$ & $\begin{array}{c}-0.0275 \\
(0.0172)\end{array}$ \\
\hline Age 63- & $\begin{array}{c}-0.0222 \\
(0.0154)\end{array}$ & $\begin{array}{c}-0.0297 \\
(0.0204)\end{array}$ \\
\hline \multicolumn{3}{|l|}{ individual SES } \\
\hline education & $\begin{array}{c}-0.00918^{* *} \\
(0.00340)\end{array}$ & $\begin{array}{r}-0.0100^{* *} \\
(0.00474)\end{array}$ \\
\hline income & $\begin{array}{c}-0.0197^{* * *} \\
(0.00519)\end{array}$ & $\begin{array}{c}-0.0183^{* * *} \\
(0.00594)\end{array}$ \\
\hline employed & $\begin{array}{c}-0.0335^{* * *} \\
(0.0100)\end{array}$ & $\begin{array}{r}-0.0293^{*} \\
(0.0155)\end{array}$ \\
\hline parental background & & $\checkmark$ \\
\hline perception of institutions & & $\checkmark$ \\
\hline social capital & & $\checkmark$ \\
\hline Country dummies & $\checkmark$ & $\checkmark$ \\
\hline $\begin{array}{l}\text { Observations } \\
R^{2}\end{array}$ & $\begin{array}{r}36259 \\
0.0318\end{array}$ & $\begin{array}{l}18939 \\
0.0385\end{array}$ \\
\hline
\end{tabular}

Notes: Dependent variable is the absolute difference between the second life satisfaction question and the first life satisfaction question. OLS - Coefficients are reported. Standard errors are clustered at the country level. Significance levels: $* p<0.1$, ${ }^{* *}$ $p<0.05,{ }^{* * *} p<0.01$.

Table 2: Determinants of absolute difference in answers to the two life satisfaction questions 
To assess the salience of the life satisfaction response differences which we have analysed, in Table A1 we estimate two separate life satisfaction regressions (in levels) similar to those used in the happiness literature. In column 1, we use the first question $\left(S_{1}\right)$ as a dependent variable, while in column 2 we run exactly the same specification using the second life satisfaction question $\left(S_{2}\right)$; for comparability, both questions are coded on a 1-5 scale). ${ }^{20}$ Columns 3 and 4 test for the equality of each pair of coefficients and show that we can reject equivalence for five out of the ten independent variables. When life satisfaction is proxied with the second question, education, income and father's education exhibit a stronger effect (with the latter coefficient turning from insignificant in column 1 to significant in column 2). The higher coefficient on age and the lower coefficient on age squared in column 2 suggest that the U-shaped effect is flatter when the dependent variable is obtained from answers to the second life satisfaction question (both regressions show that happiness reaches its nadir when respondents are around 42 years old). In other words, while the correlates of the two well-being questions appear broadly similar in our data, there are several disparities which researchers should take into account. The magnitude and sign of the coefficients in Table A1 are very similar to those obtained in other cross-country work (using the World Values Survey) covering both transition and non-transition countries (Guriev and Zhuravskaya, 2009; Sanfey and Teksoz, 2007), which indicates that the results in this paper are not driven by the idiosyncrasies of the LiTS.

\section{$5 \quad$ Extensions and robustness}

We test the robustness of our results in Table 3. In each case, we take the inclusive version of the model; that is, the equivalent of column 6 in Table 1. To further alleviate concerns about local-level unobservable characteristics, Column 1 replaces the country dummies with dummies at the level of sub-national administrative regions. Instead, column 2 includes dummies at the primary sampling unit level (PSU), which essentially implies that we are comparing

\footnotetext{
${ }^{20}$ Including number of children in the household (in unreported specifications) does not change these results.
} 
individuals within very small geographic units such as villages or city neighbourhoods (both specifications cluster the errors at either the regional or PSU level). Finally, column 3 introduces interviewer dummies. ${ }^{21}$ In all three cases, the results are broadly consistent with those in Table 1, although sometimes in columns 2 and 3, they are less precisely estimated, possibly because we are dropping useful variation from our estimations. ${ }^{22}$

Are the life satisfaction biases which we uncover different across transition and nontransition countries? Keeping in mind the caveat that our sample contains only six nontransition countries (Turkey, Germany, France, Italy, Sweden and the UK), in Table A2 we present results from interacting our independent variables with a transition country dummy (only variables with significant interaction terms are reported to conserve space). We find that in transition countries those who are healthier, married and more trusting of institutions are more likely to report a lower life satisfaction score in the second question, while those who are richer are more likely to overreport happiness in the second question. None of the transition dummy interactions with the other independent variables are significant, suggesting that response inconsistencies are similar across transition and non-transition countries.

We implement multiple additional robustness test in the online Appendix, including multinomial logit and ordered probit specifications; controlling for interview day and time and interview duration; and several different codings of our dependent variable (including a standardised difference). In all cases, results are very similar to those presented in the baseline specification.

\footnotetext{
${ }^{21}$ Interviewer information is not available for Italy.

${ }^{22}$ Since income and the extent to which the respondent meets up with friends lose significance in column 2 , we also ran specifications in which we include the average value of these variables for all respondents in the individual's PSU (excluding the respondent himself/herself). Our results indicate that this specification explains around $46 \%$ of the observed variation in individual income and around $39 \%$ of the observed variation in the individual propensity to meet up with friends, likely because these variables are highly correlated at the local level.
} 


\begin{tabular}{|c|c|c|c|}
\hline & $\begin{array}{c}(1) \\
\text { nine-point difference }\end{array}$ & $\begin{array}{c}(2) \\
\text { nine-point difference }\end{array}$ & $\begin{array}{c}(3) \\
\text { nine-point difference }\end{array}$ \\
\hline \multicolumn{4}{|l|}{ baseline } \\
\hline health & $\begin{array}{r}0.0250^{*} \\
(0.0137)\end{array}$ & $\begin{array}{c}0.0200 \\
(0.0126)\end{array}$ & $\begin{array}{c}0.0198 \\
(0.0126)\end{array}$ \\
\hline married & $\begin{array}{c}0.00501 \\
(0.0179)\end{array}$ & $\begin{array}{c}0.0247 \\
(0.0186)\end{array}$ & $\begin{array}{c}0.0277 \\
(0.0198)\end{array}$ \\
\hline Age $18-22$ & $\begin{array}{c}-0.0126 \\
(0.0417)\end{array}$ & $\begin{array}{c}-0.00778 \\
(0.0413)\end{array}$ & $\begin{array}{c}0.0152 \\
(0.0423)\end{array}$ \\
\hline Age 23-32 & $\begin{array}{r}-0.0440^{*} \\
(0.0236)\end{array}$ & $\begin{array}{c}-0.0264 \\
(0.0270)\end{array}$ & $\begin{array}{c}-0.0235 \\
(0.0307)\end{array}$ \\
\hline Age $33-42$ & $\begin{array}{c}-0.00109 \\
(0.0219)\end{array}$ & $\begin{array}{c}0.0106 \\
(0.0251)\end{array}$ & $\begin{array}{c}0.0115 \\
(0.0279)\end{array}$ \\
\hline Age $53-62$ & $\begin{array}{c}0.0154 \\
(0.0288)\end{array}$ & $\begin{array}{r}0.00437 \\
(0.0280)\end{array}$ & $\begin{array}{r}0.00827 \\
(0.0293)\end{array}$ \\
\hline Age 63- & $\begin{array}{c}0.00559 \\
(0.0385)\end{array}$ & $\begin{array}{r}-0.00308 \\
(0.0315)\end{array}$ & $\begin{array}{c}-0.0379 \\
(0.0318)\end{array}$ \\
\hline education & $\begin{array}{c}0.0136^{*} \\
(0.00749)\end{array}$ & $\begin{array}{r}0.0168^{* *} \\
(0.00767)\end{array}$ & $\begin{array}{c}0.00975 \\
(0.00811)\end{array}$ \\
\hline income & $\begin{array}{l}0.0243^{* * *} \\
(0.00687)\end{array}$ & $\begin{array}{l}0.0101 \\
(0.00732)\end{array}$ & $\begin{array}{c}0.0131^{*} \\
(0.00756)\end{array}$ \\
\hline employed & $\begin{array}{c}0.0188 \\
(0.0190)\end{array}$ & $\begin{array}{c}0.00749 \\
(0.0213)\end{array}$ & $\begin{array}{c}-0.0200 \\
(0.0213)\end{array}$ \\
\hline \multicolumn{4}{|l|}{ parental background } \\
\hline father's education & $\begin{array}{l}0.00823^{* * *} \\
(0.00292)\end{array}$ & $\begin{array}{l}0.00882^{* * *} \\
(0.00260)\end{array}$ & $\begin{array}{l}0.00977^{* * *} \\
(0.00273)\end{array}$ \\
\hline affected by war & $\begin{array}{c}0.0157 \\
(0.0197)\end{array}$ & $\begin{array}{c}0.0109 \\
(0.0209)\end{array}$ & $\begin{array}{c}0.0167 \\
(0.0220)\end{array}$ \\
\hline \multicolumn{4}{|l|}{ perception of institutions } \\
\hline trust institutions & $\begin{array}{l}-0.0879^{* * *} \\
(0.0154)\end{array}$ & $\begin{array}{l}-0.0839^{* * *} \\
(0.0165)\end{array}$ & $\begin{array}{l}-0.0743^{* * *} \\
(0.0177)\end{array}$ \\
\hline effective institutions exist & $\begin{array}{l}-0.0787^{* * *} \\
(0.0273)\end{array}$ & $\begin{array}{l}-0.0645^{* * *} \\
(0.0189)\end{array}$ & $\begin{array}{l}-0.0823^{* * *} \\
(0.0189)\end{array}$ \\
\hline political liberties exist & $\begin{array}{l}0.0449^{* *} \\
(0.0200)\end{array}$ & $\begin{array}{r}0.0372^{*} \\
(0.0222)\end{array}$ & $\begin{array}{c}0.0158 \\
(0.0223)\end{array}$ \\
\hline corruption exists & $\begin{array}{r}-0.000257 \\
(0.00181)\end{array}$ & $\begin{array}{r}-0.000180 \\
(0.00224)\end{array}$ & $\begin{array}{c}-0.000853 \\
(0.00244)\end{array}$ \\
\hline incomes should be more equal & $\begin{array}{l}-0.0591^{* * *} \\
(0.0204)\end{array}$ & $\begin{array}{l}-0.0470^{* *} \\
(0.0218)\end{array}$ & $\begin{array}{l}-0.0442^{* *} \\
(0.0224)\end{array}$ \\
\hline \multicolumn{4}{|l|}{ social capital } \\
\hline meet up with friends & $\begin{array}{c}0.0164^{*} \\
(0.00957)\end{array}$ & $\begin{array}{c}0.0101 \\
(0.0110)\end{array}$ & $\begin{array}{c}0.00221 \\
(0.0109)\end{array}$ \\
\hline member of a political party & $\begin{array}{c}-0.0706 \\
(0.0484)\end{array}$ & $\begin{array}{r}-0.0691^{*} \\
(0.0382)\end{array}$ & $\begin{array}{c}-0.0311 \\
(0.0377)\end{array}$ \\
\hline active member of organizations & $\begin{array}{l}0.0318^{* *} \\
(0.0129)\end{array}$ & $\begin{array}{l}0.0290^{*} \\
(0.0150)\end{array}$ & $\begin{array}{c}0.0147 \\
(0.0136)\end{array}$ \\
\hline Region dummies & $\checkmark$ & & \\
\hline PSU dummies & & $\checkmark$ & \\
\hline Interviewer dummies & & & $\checkmark$ \\
\hline $\begin{array}{l}\text { Observations } \\
R^{2}\end{array}$ & $\begin{array}{l}18939 \\
0.131\end{array}$ & $\begin{array}{l}18939 \\
0.260\end{array}$ & $\begin{array}{l}18176 \\
0.296\end{array}$ \\
\hline
\end{tabular}

Notes: OLS - Coefficients are reported. Standard errors are clustered at the country level. Significance levels: ${ }^{*} p<0.1,{ }^{* *} p<0.05,{ }^{* * *} p<0.01$.

\section{Table 3: Robustness table}




\section{Conclusion}

We exploit the rare opportunity to observe answers to two similar life satisfaction questions asked during the same interview in the Life in Transition Survey. We conclude that the ordering and wording of questions on subjective well-being can influence the responses, and that this fact should be taken into account when designing household questionnaires and interpreting the resulting data. To summarise: we found that there is a high degree of consistency between the answers to the two questions on life satisfaction. That is good news for the happiness literature, because it helps to rebut the view that data on subjective wellbeing are noisy and unduly influenced by whims. Furthermore, our findings that sensitive questions on institutions and corruption do not bias responses in the second life satisfaction question downward is encouraging, particularly in light of the opposite conclusion reached by Deaton (2012) for the US. Similarly, the effects of age and health are less robust across specifications.

However, our analysis also shows that for around $14 \%$ of respondents, life satisfaction changed significantly from the first to the second question. Intervening questions related to individual SES, parental background and social capital can trigger changes in well-being, perhaps by reminding people of pleasant or unpleasant aspects of their lives. We also find that the life satisfaction responses of those who have less income, education or are unemployed are more noisy.

These results suggest that researchers studying the determinants of life satisfaction may wish to run robustness tests on those sub-samples of respondents which we identified as more prone to imprecise answers. Although our research design lacks question randomization, we believe that our results - which survive multiple robustness checks - provide important insights for designing life satisfation questions in future surveys.

\section{References}

Chadi, Adrian, 2013. The role of interviewer encounters in panel responses on life satisfaction. Economics Letters 121, 550-554. 
Chadi, Adrian, 2014. Dissatisfied with life or with being interviewed? Happiness and motivation to participate in a survey. SOEP Working paper 639.

Cojocaru, Alexandru, 2014. Fairness and inequality tolerance: Evidence from the life in transition survey. Journal of Comparative Economics 42, 590-608.

Cojocaru, Alexandru, Diagne, Mame Fatou, 2015. How reliable and consistent are subjective measures of welfare in Europe and Central Asia? Economics of Transition 23, 75-103.

Conti, Gabriella, Pudney, Stephen, 2011. Survey design and the analysis of satisfaction. Review of Economics and Statistics 93, 1087-1093.

Dabalen, Andrew, Paul, Saumik, 2011. History of events and life-satisfaction in transition countries. World Bank Policy Research Working Paper 5526.

Deaton, Angus, 2012. The financial crisis and the well-being of Americans 2011 OEP Hicks Lecture. Oxford Economic Papers 64, 1-26.

Diener, Ed, Inglehart, Ronald, Tay, Louis, 2013. Theory and validity of life satisfaction scales. Social Indicators Research 112, 497-527.

Djankov, Simeon, Nikolova, Elena, Zilinsky, Jan, 2015. The happiness gap in Eastern Europe. Working paper.

Dolan, Paul, Kavetsos, Georgios, 2012. Happy talk: Mode of administration effects on subjective well-being. CEP Discussion Paper 1159.

Ferrer-i Carbonell, Ada, Frijters, Paul, 2004. How important is methodology for the estimates of the determinants of happiness? Economic Journal 114, 641-659.

Frey, Bruno S, Stutzer, Alois, 2010. Happiness and Economics: How the Economy and Institutions Affect Human Well-being. Princeton Univ. Press, Princeton, NJ.

Guriev, Sergei, Zhuravskaya, Ekaterina, 2009. (Un)happiness in transition. Journal of Economic Perspectives 23, 143-68.

Heffetz, Ori, Rabin, Matthew, 2013. Conclusions regarding cross-group differences in happiness depend on difficulty of reaching respondents. American Economic Review 103, 30013021.

Helliwell, John F, Layard, Richard, Sachs, Jeffrey, 2013. World Happiness Report 2013. Sustainable Development Solutions Network.

Kahneman, Daniel, Krueger, Alan B, 2006. Developments in the measurement of subjective well-being. Journal of Economic Perspectives 20, 3-24.

Kassenboehmer, Sonja C, Haisken-DeNew, John P, 2012. Heresy or enlightenment? The well-being age U-shape effect is flat. Economics Letters 117, 235-238.

Kavetsos, Georgios, Dimitriadou, Marika, Dolan, Paul, 2014. Measuring happiness: Context matters. Applied Economics Letters 21, 308-311. 
Kornai, Janos, 2006. The great transformation of Central Eastern Europe. Economics of Transition 14, 207-244.

Krueger, Alan B, Schkade, David A, 2008. The reliability of subjective well-being measures. Journal of Public Economics 92, 1833-1845.

Layard, Richard, 2005. Happiness: Lessons from a New Science. Allen Lane, London.

Podsakoff, Philip M, MacKenzie, Scott B, Lee, Jeong-Yeon, Podsakoff, Nathan P, 2003. Common method biases in behavioral research: a critical review of the literature and recommended remedies. Journal of Applied Psychology 88, 879.

Popova, Olga, 2014. Can religion insure against aggregate shocks to happiness? The case of transition countries. Journal of Comparative Economics 42, 804-818.

Powdthavee, Nick, 2010. The Happiness Equation: The Surprising Economics of Our Most Valuable Asset. Icon Books, London.

Sanfey, Peter, Teksoz, Utku, 2007. Does transition make you happy? Economics of Transition $15,707-731$.

Schimmack, Ulrich, Oishi, Shigehiro, 2005. The influence of chronically and temporarily accessible information on life satisfaction judgments. Journal of Personality and Social Psychology 89, 395.

Schwarz, Norbert, 1999. Self-reports: How the questions shape the answers. American Psychologist 54, 93.

Senik, Claudia, 2009. Direct evidence on income comparisons and their welfare effects. Journal of Economic Behavior \& Organization 72, 408-424.

Studer, Raphael, 2012. Does it matter how happiness is measured? Evidence from a randomized controlled experiment. Journal of Economic and Social Measurement 37, 317-336. 


\section{ONLINE APPENDIX (NOT FOR PUBLICATION)}

Additional figures and tables

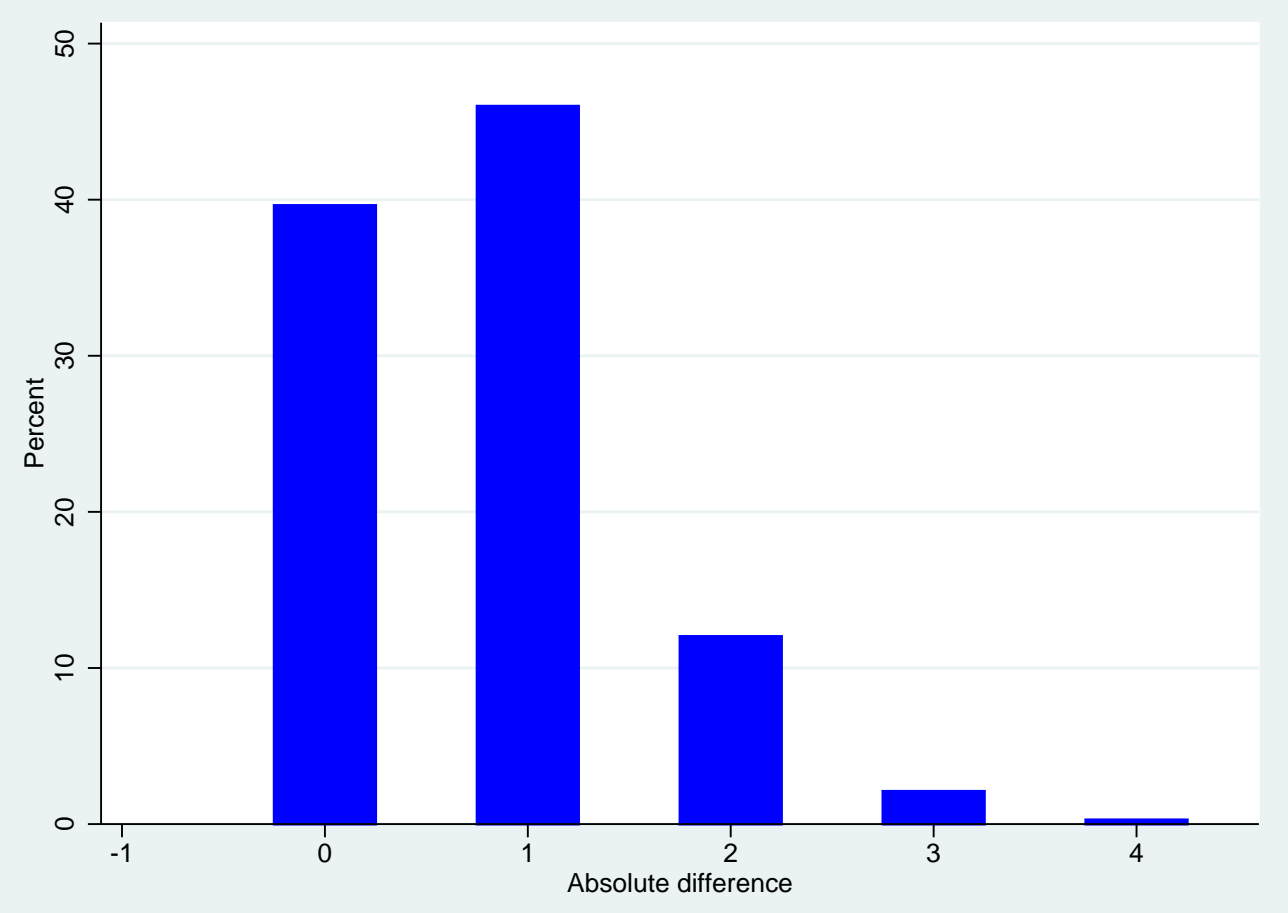

Figure A1: Histogram of the absolute difference in responses 


\begin{tabular}{|c|c|c|c|c|}
\hline & $\begin{array}{l}(1) \\
\text { S1 }\end{array}$ & $\begin{array}{l}(2) \\
\text { S2 }\end{array}$ & $\begin{array}{l}(3) \\
\chi^{2}\end{array}$ & $\begin{array}{c}(4) \\
\text { p-value }\end{array}$ \\
\hline health & $\begin{array}{l}0.163^{* * *} \\
(0.0107)\end{array}$ & $\begin{array}{l}0.169^{* * *} \\
(0.0120)\end{array}$ & 0.34 & 0.560 \\
\hline married & $\begin{array}{l}0.123^{* * *} \\
(0.0145)\end{array}$ & $\begin{array}{l}0.121^{* * *} \\
(0.0170)\end{array}$ & 0.01 & 0.933 \\
\hline age & $\begin{array}{c}-0.0273^{* * *} \\
(0.00293)\end{array}$ & $\begin{array}{c}-0.0193^{* * *} \\
(0.00292)\end{array}$ & 9.74 & 0.002 \\
\hline age2 & $\begin{array}{c}0.000319^{* * *} \\
(0.0000300)\end{array}$ & $\begin{array}{c}0.000232^{* * *} \\
(0.0000314)\end{array}$ & 14.10 & 0.000 \\
\hline male & $\begin{array}{c}-0.0569^{* * *} \\
(0.0176)\end{array}$ & $\begin{array}{c}-0.0530^{* * *} \\
(0.0164)\end{array}$ & 0.06 & 0.799 \\
\hline education & $\begin{array}{l}0.0312^{* * *} \\
(0.00711)\end{array}$ & $\begin{array}{l}0.0470^{* * *} \\
(0.00821)\end{array}$ & 6.52 & 0.011 \\
\hline income & $\begin{array}{l}0.205^{* * *} \\
(0.0117)\end{array}$ & $\begin{array}{l}0.226^{* * *} \\
(0.0125)\end{array}$ & 7.79 & 0.053 \\
\hline employed & $\begin{array}{l}0.0372^{* *} \\
(0.0178)\end{array}$ & $\begin{array}{l}0.0375^{* *} \\
(0.0161)\end{array}$ & 0.00 & 0.986 \\
\hline father's education & $\begin{array}{c}-0.00184 \\
(0.00255)\end{array}$ & $\begin{array}{l}0.00850^{* * *} \\
(0.00210)\end{array}$ & 16.05 & 0.000 \\
\hline affected by war & $\begin{array}{c}0.00630 \\
(0.0190)\end{array}$ & $\begin{array}{c}0.0241 \\
(0.0197)\end{array}$ & 0.72 & 0.395 \\
\hline Country dummies & $\checkmark$ & $\checkmark$ & & \\
\hline $\begin{array}{l}\text { Observations } \\
R^{2}\end{array}$ & $\begin{array}{r}25427 \\
0.266\end{array}$ & $\begin{array}{r}25666 \\
0.343\end{array}$ & & \\
\hline
\end{tabular}

Notes: Standard errors are clustered at the country level. Significance levels: ${ }^{*} p<0.1$, ** $p<0.05,{ }^{* * *} p<0.01$.

Table A1: Life satisfaction regressions using S1 and S2 


\begin{tabular}{|c|c|}
\hline & $\begin{array}{c}(1) \\
\text { nine-point difference }\end{array}$ \\
\hline transition & $\begin{array}{c}-0.0762 \\
(0.309)\end{array}$ \\
\hline health & $\begin{array}{l}0.0593^{* * *} \\
(0.0167)\end{array}$ \\
\hline health $*$ transition & $\begin{array}{c}-0.0519^{* *} \\
(0.0241)\end{array}$ \\
\hline married & $\begin{array}{l}0.0884^{* * *} \\
(0.0161)\end{array}$ \\
\hline married $*$ transition & $\begin{array}{l}-0.138^{* * *} \\
(0.0262)\end{array}$ \\
\hline income & $\begin{array}{r}-0.00616 \\
(0.00713)\end{array}$ \\
\hline income $*$ transition & $\begin{array}{l}0.0532^{* * *} \\
(0.0114)\end{array}$ \\
\hline trust institutions & $\begin{array}{r}-0.0549 \\
(0.0369)\end{array}$ \\
\hline trust institutions $*$ transition & $\begin{array}{r}-0.101^{* *} \\
(0.0423)\end{array}$ \\
\hline $\begin{array}{l}\text { Country dummies } \\
\text { Other controls and interactions }\end{array}$ & $\checkmark$ \\
\hline $\begin{array}{l}\text { Observations } \\
R^{2}\end{array}$ & $\begin{array}{r}18940 \\
0.0381\end{array}$ \\
\hline \multicolumn{2}{|c|}{$\begin{array}{l}\text { Notes: Dependent variable is the nine-point difference } \\
\text { between the second life satisfaction question and the } \\
\text { first life satisfaction question. OLS - Coefficients are } \\
\text { reported. Standard errors are clustered at the country } \\
\text { level. Significance levels: }{ }^{*} p<0.1,{ }^{* *} p<0.05 \text {, } * * * \\
p<0.01 \text {. }\end{array}$} \\
\hline
\end{tabular}

Table A2: Examining the difference in response biases between transition and non-transition countries

\section{Additional robustness checks}

In Tables A3 and A4, we relax the cardinality assumption on which our OLS regressions are based and show that our results are robust to using ordinal models (multinomial logit and ordered probit; marginal coefficients are reported in both tables). Following Conti and Pudney (2011), in Table A3 we distinguish three states: $S_{2}>S_{1}, S_{2}<S_{1}$ and $S_{2}=S_{1}$ (the latter being the reference category). To conserve space in Table A4, we only report the coefficient estimates for the difference categories $-2,0$ and 2. Results are broadly in line with our baseline specification: respondents with low socioeconomic status are more likely to under-report happiness in the second question, while those with social capital are less likely to record a lower life satisfaction score in the second question. The results on institutional 
perceptions and income equality also survive.

In Table A5, we control for interview day and time and interview duration. Although results are largely consistent, estimates should be treated with caution since data limitations shrink our sample considerably. ${ }^{23}$ In unreported specifications, we failed to find an interaction effect between interview duration and any of our independent variables, though of course this could arise from attenuation bias due to measurement error in the duration variable.

We probe the sensitivity of our results to an alternative and more flexible coding scheme of our dependent variable in Table A6. More precisely, if the respondent gave an answer of 1 or 2 in the first question, we regarded any answer of $1,2,3$, or 4 in the second question as consistent and coded these cases as having a difference score of 0 . For respondents who picked either 1 or 2 in the first question but 5 or 6 in the second question, we coded a difference score of 1 . If a respondent picked 1 or 2 in the first question but $7,8,9$ or 10 in the second question, then the difference score takes a value of 2. Following a similar logic, respondents with a life satisfaction score in the first question of 4 or 5 can pick 7, 8, 9 or 10 in the second question (for a difference score of 0 ), 5 or 6 (for a difference score of -1) and 1,2, 3 or 4 (for a difference score of -2). Respondents who picked the middle category in the first question (3) can choose either 5 or 6 in the second question (for a difference score of 0 ), 1, 2, 3 or 4 (for a difference score of -1 ), or 7, 8, 9 or 10 (for a difference score of 1). As a result, the dependent variable now ranges from -2 to 2 . The results in Table A6 are very similar to those we presented earlier. In Table A7, our dependent variable is the nine-point difference between the second life satisfaction question and the first life satisfaction question, assigning the 6 category in the second question to the "agree" category in the first question. We adopt this approach because respondents may not treat the 6 category as a mid-point on the 1-10 scale. Results are unchanged from the baseline specification.

In unreported specifications, we experimented with additional specifications of the dependent variable. First, we recoded our dependent variable as a standardised difference; that is, converting S1 and S2 to standardised scores (subtracting the mean across all observations and

\footnotetext{
${ }^{23}$ Although interview duration may be endogenous to various individual characteristics, we do not find that any of our independent variables explain it in our sample.
} 
dividing by the standard deviation) and taking the difference. In a different specification, we dropped difference scores of -4 and 4 . In a third specification, we calculated $\mathrm{S} 2$ by dividing response scores by 2. Finally, we also recoded the responses to S2 to mimic the distribution of responses of S1. In all variants, the main conclusions derived from the model estimated earlier still hold. 


\begin{tabular}{|c|c|c|}
\hline & $\begin{array}{c}(1) \\
\operatorname{Pr}(S 2>S 1)\end{array}$ & $\begin{array}{c}(2) \\
\operatorname{Pr}(\mathrm{S} 2<\mathrm{S} 1)\end{array}$ \\
\hline \multicolumn{3}{|l|}{$\underline{\text { baseline }}$} \\
\hline health & $\begin{array}{c}0.00668 \\
(0.00502)\end{array}$ & $\begin{array}{c}-0.00768 \\
(0.00684)\end{array}$ \\
\hline married & $\begin{array}{c}0.00998 \\
(0.00639)\end{array}$ & $\begin{array}{c}-0.00227 \\
(0.00938)\end{array}$ \\
\hline Age $18-22$ & $\begin{array}{c}-0.00773 \\
(0.0193)\end{array}$ & $\begin{array}{r}-0.0137 \\
(0.0193)\end{array}$ \\
\hline Age $23-32$ & $\begin{array}{c}-0.0111 \\
(0.0112)\end{array}$ & $\begin{array}{c}0.0157 \\
(0.0127)\end{array}$ \\
\hline Age $33-42$ & $\begin{array}{c}0.00197 \\
(0.00801)\end{array}$ & $\begin{array}{c}0.00389 \\
(0.0110)\end{array}$ \\
\hline Age $53-62$ & $\begin{array}{c}0.00383 \\
(0.0101)\end{array}$ & $\begin{array}{c}-0.0128 \\
(0.0127)\end{array}$ \\
\hline Age 63- & $\begin{array}{c}-0.00454 \\
(0.0103)\end{array}$ & $\begin{array}{c}0.0101 \\
(0.0153)\end{array}$ \\
\hline \multicolumn{3}{|l|}{$\underline{\text { individual SES }}$} \\
\hline education & $\begin{array}{c}-0.0000309 \\
(0.00275)\end{array}$ & $\begin{array}{l}-0.00811^{* * *} \\
(0.00273)\end{array}$ \\
\hline income & $\begin{array}{c}0.00368 \\
(0.00335)\end{array}$ & $\begin{array}{c}-0.0171^{* * *} \\
(0.00309)\end{array}$ \\
\hline employed & $\begin{array}{c}-0.00259 \\
(0.00871)\end{array}$ & $\begin{array}{c}-0.00349 \\
(0.0107)\end{array}$ \\
\hline \multicolumn{3}{|l|}{$\underline{\text { parental background }}$} \\
\hline father's education & $\begin{array}{c}0.00303^{* * *} \\
(0.000905)\end{array}$ & $\begin{array}{c}-0.00346^{* * *} \\
(0.00120)\end{array}$ \\
\hline affected by war & $\begin{array}{c}0.0143^{*} \\
(0.00860)\end{array}$ & $\begin{array}{c}-0.0103 \\
(0.00986)\end{array}$ \\
\hline \multicolumn{3}{|l|}{ perception of institutions } \\
\hline trust institutions & $\begin{array}{c}-0.0333^{* * *} \\
(0.00670)\end{array}$ & $\begin{array}{l}0.0270^{* * *} \\
(0.00751)\end{array}$ \\
\hline effective institutions exist & $\begin{array}{c}-0.0248^{* * *} \\
(0.00826)\end{array}$ & $\begin{array}{l}0.0348^{* * *} \\
(0.00842)\end{array}$ \\
\hline political liberties exist & $\begin{array}{c}0.00123 \\
(0.00851)\end{array}$ & $\begin{array}{r}-0.00650 \\
(0.00798)\end{array}$ \\
\hline corruption exists & $\begin{array}{c}-0.0000553 \\
(0.000586)\end{array}$ & $\begin{array}{c}-0.00124 \\
(0.000969)\end{array}$ \\
\hline incomes should be more equal & $\begin{array}{r}-0.0192^{* *} \\
(0.00876)\end{array}$ & $\begin{array}{l}0.0249^{* * *} \\
(0.00919)\end{array}$ \\
\hline \multicolumn{3}{|l|}{$\underline{\text { social capital }}$} \\
\hline meet up with friends & $\begin{array}{c}0.00431 \\
(0.00400)\end{array}$ & $\begin{array}{c}-0.0122^{* * *} \\
(0.00392)\end{array}$ \\
\hline member of a political party & $\begin{array}{c}-0.00206 \\
(0.0173)\end{array}$ & $\begin{array}{l}0.0379^{* * *} \\
(0.0137)\end{array}$ \\
\hline active member of organizations & $\begin{array}{c}0.00454 \\
(0.00542)\end{array}$ & $\begin{array}{c}-0.0130^{*} \\
(0.00732)\end{array}$ \\
\hline Country dummies & $\checkmark$ & $\checkmark$ \\
\hline Observations & 18940 & 18940 \\
\hline
\end{tabular}

Notes: Marginal coefficients are reported. Standard errors are clustered at the country level. Significance levels: ${ }^{*} p<0.1$, ${ }^{* *} p<0.05,{ }^{* * *} p<0.01$.

Table A3: Multinomial logit specification 


\begin{tabular}{|c|c|c|c|}
\hline \multicolumn{4}{|l|}{$\underline{\text { baseline }}$} \\
\hline health & $\begin{array}{c}-0.00242^{*} \\
(0.00142)\end{array}$ & $\begin{array}{c}0.00115^{*} \\
(0.000692)\end{array}$ & $\begin{array}{c}0.00189^{*} \\
(0.00110)\end{array}$ \\
\hline married & $\begin{array}{c}-0.00106 \\
(0.00192)\end{array}$ & $\begin{array}{c}0.000503 \\
(0.000933)\end{array}$ & $\begin{array}{c}0.000823 \\
(0.00150)\end{array}$ \\
\hline Age 18-22 & $\begin{array}{l}0.00000590 \\
(0.00533)\end{array}$ & $\begin{array}{c}-0.00000281 \\
(0.00254)\end{array}$ & $\begin{array}{c}-0.00000460 \\
(0.00416)\end{array}$ \\
\hline Age $23-32$ & $\begin{array}{c}0.00447 \\
(0.00297)\end{array}$ & $\begin{array}{c}-0.00213 \\
(0.00141)\end{array}$ & $\begin{array}{c}-0.00348 \\
(0.00231)\end{array}$ \\
\hline Age $33-42$ & $\begin{array}{l}0.0000833 \\
(0.00213)\end{array}$ & $\begin{array}{c}-0.0000397 \\
(0.00101)\end{array}$ & $\begin{array}{c}-0.0000650 \\
(0.00166)\end{array}$ \\
\hline Age $53-62$ & $\begin{array}{c}-0.00250 \\
(0.00333)\end{array}$ & $\begin{array}{c}0.00119 \\
(0.00159)\end{array}$ & $\begin{array}{c}0.00195 \\
(0.00259)\end{array}$ \\
\hline Age 63- & $\begin{array}{c}0.000403 \\
(0.00315)\end{array}$ & $\begin{array}{c}-0.000192 \\
(0.00150)\end{array}$ & $\begin{array}{c}-0.000314 \\
(0.00246)\end{array}$ \\
\hline \multicolumn{4}{|l|}{ individual SES } \\
\hline education & $\begin{array}{c}-0.00130^{*} \\
(0.000707)\end{array}$ & $\begin{array}{c}0.000618^{*} \\
(0.000337)\end{array}$ & $\begin{array}{c}0.00101^{*} \\
(0.000577)\end{array}$ \\
\hline income & $\begin{array}{c}-0.00358^{* * *} \\
(0.000981)\end{array}$ & $\begin{array}{c}0.00170^{* * *} \\
(0.000438)\end{array}$ & $\begin{array}{c}0.00279^{* * *} \\
(0.000782)\end{array}$ \\
\hline employed & $\begin{array}{c}-0.000974 \\
(0.00263)\end{array}$ & $\begin{array}{c}0.000464 \\
(0.00125)\end{array}$ & $\begin{array}{c}0.000760 \\
(0.00205)\end{array}$ \\
\hline \multicolumn{4}{|l|}{ parental background } \\
\hline father's education & $\begin{array}{c}-0.00105^{* * *} \\
(0.000313)\end{array}$ & $\begin{array}{l}0.000502^{\text {*** }} \\
(0.000154)\end{array}$ & $\begin{array}{l}0.000822^{* * *} \\
(0.000242)\end{array}$ \\
\hline affected by war & $\begin{array}{c}-0.00318 \\
(0.00266)\end{array}$ & $\begin{array}{c}0.00152 \\
(0.00123)\end{array}$ & $\begin{array}{c}0.00248 \\
(0.00203)\end{array}$ \\
\hline \multicolumn{4}{|l|}{ perception of institutions } \\
\hline trust institutions & $\begin{array}{l}0.0102^{* * *} \\
(0.00217)\end{array}$ & $\begin{array}{c}-0.00484^{* * *} \\
(0.000960)\end{array}$ & $\begin{array}{c}-0.00793^{* * *} \\
(0.00173)\end{array}$ \\
\hline effective institutions exist & $\begin{array}{l}0.0108^{* * *} \\
(0.00264)\end{array}$ & $\begin{array}{c}-0.00516^{* * *} \\
(0.00108)\end{array}$ & $\begin{array}{c}-0.00845^{* * *} \\
(0.00201)\end{array}$ \\
\hline political liberties exist & $\begin{array}{c}-0.00132 \\
(0.00256)\end{array}$ & $\begin{array}{c}0.000629 \\
(0.00120)\end{array}$ & $\begin{array}{c}0.00103 \\
(0.00199)\end{array}$ \\
\hline corruption exists & $\begin{array}{c}-0.000169 \\
(0.000230)\end{array}$ & $\begin{array}{c}0.0000805 \\
(0.000109)\end{array}$ & $\begin{array}{c}0.000132 \\
(0.000180)\end{array}$ \\
\hline incomes should be more equal & $\begin{array}{l}0.00703^{* * *} \\
(0.00251)\end{array}$ & $\begin{array}{c}-0.00335^{* * *} \\
(0.00107)\end{array}$ & $\begin{array}{c}-0.00549^{* * *} \\
(0.00196)\end{array}$ \\
\hline \multicolumn{4}{|l|}{ social capital } \\
\hline meet up with friends & $\begin{array}{c}-0.00297^{* *} \\
(0.00118)\end{array}$ & $\begin{array}{r}0.00142^{* *} \\
(0.000559)\end{array}$ & $\begin{array}{r}0.00232^{* *} \\
(0.000937)\end{array}$ \\
\hline member of a political party & $\begin{array}{c}0.00791 \\
(0.00497)\end{array}$ & $\begin{array}{r}-0.00377^{*} \\
(0.00228)\end{array}$ & $\begin{array}{c}-0.00617 \\
(0.00396)\end{array}$ \\
\hline active member of organizations & $\begin{array}{r}-0.00212^{*} \\
(0.00126)\end{array}$ & $\begin{array}{c}0.00101 \\
(0.000626)\end{array}$ & $\begin{array}{c}0.00166 \\
(0.00101)\end{array}$ \\
\hline \multicolumn{4}{|l|}{ Country dummies } \\
\hline $\begin{array}{l}\text { Mean } \\
\text { Observations }\end{array}$ & 18940 & 18940 & 18940 \\
\hline
\end{tabular}

Notes: Marginal coefficients are reported. Standard errors are clustered at the country level. Significance levels: ${ }^{*} p<0.1,{ }^{* *} p<0.05,{ }^{* * *} p<0.01$.

Table A4: Ordered probit specification 


\begin{tabular}{|c|c|c|c|}
\hline & $\begin{array}{c}(1) \\
\text { nine-point difference }\end{array}$ & $\begin{array}{c}(2) \\
\text { nine-point difference }\end{array}$ & $\begin{array}{c}(3) \\
\text { nine-point difference }\end{array}$ \\
\hline interview duration & & $\begin{array}{c}0.00173 \\
(0.00154)\end{array}$ & $\begin{array}{c}0.000755 \\
(0.000769)\end{array}$ \\
\hline \multicolumn{4}{|l|}{$\underline{\text { baseline }}$} \\
\hline health & $\begin{array}{c}-0.00599 \\
(0.0199)\end{array}$ & $\begin{array}{c}-0.00549 \\
(0.0200)\end{array}$ & $\begin{array}{c}0.0208 \\
(0.0166)\end{array}$ \\
\hline married & $\begin{array}{l}-0.0348 \\
(0.0238)\end{array}$ & $\begin{array}{l}-0.0350 \\
(0.0240)\end{array}$ & $\begin{array}{c}-0.0160 \\
(0.0193)\end{array}$ \\
\hline Age $18-22$ & $\begin{array}{c}0.0558 \\
(0.105)\end{array}$ & $\begin{array}{r}0.0571 \\
(0.105)\end{array}$ & $\begin{array}{c}-0.0228 \\
(0.0631)\end{array}$ \\
\hline Age $23-32$ & $\begin{array}{c}0.00384 \\
(0.0410)\end{array}$ & $\begin{array}{c}0.00433 \\
(0.0409)\end{array}$ & $\begin{array}{l}-0.0408 \\
(0.0315)\end{array}$ \\
\hline Age $33-42$ & $\begin{array}{c}0.0500 \\
(0.0339)\end{array}$ & $\begin{array}{c}0.0511 \\
(0.0340)\end{array}$ & $\begin{array}{c}0.0180 \\
(0.0187)\end{array}$ \\
\hline Age $53-62$ & $\begin{array}{c}0.0350 \\
(0.0493)\end{array}$ & $\begin{array}{c}0.0354 \\
(0.0495)\end{array}$ & $\begin{array}{c}0.00919 \\
(0.0345)\end{array}$ \\
\hline Age 63- & $\begin{array}{l}-0.0486 \\
(0.0545)\end{array}$ & $\begin{array}{c}-0.0475 \\
(0.0548)\end{array}$ & $\begin{array}{c}-0.0228 \\
(0.0326)\end{array}$ \\
\hline \multicolumn{4}{|l|}{ individual SES } \\
\hline education & $\begin{array}{c}0.0211 \\
(0.0144)\end{array}$ & $\begin{array}{c}0.0213 \\
(0.0143)\end{array}$ & $\begin{array}{l}0.0119 \\
(0.00853)\end{array}$ \\
\hline income & $\begin{array}{l}0.0600^{* * *} \\
(0.0147)\end{array}$ & $\begin{array}{l}0.0598^{* * *} \\
(0.0147)\end{array}$ & $\begin{array}{l}0.0313^{* * *} \\
(0.0101)\end{array}$ \\
\hline employed & $\begin{array}{c}0.0120 \\
(0.0505)\end{array}$ & $\begin{array}{c}0.0112 \\
(0.0504)\end{array}$ & $\begin{array}{c}-0.00381 \\
(0.0310)\end{array}$ \\
\hline \multicolumn{4}{|l|}{$\underline{\text { parental background }}$} \\
\hline father's education & $\begin{array}{c}0.00866 \\
(0.00726)\end{array}$ & $\begin{array}{c}0.00864 \\
(0.00726)\end{array}$ & $\begin{array}{l}0.0111^{* * *} \\
(0.00402)\end{array}$ \\
\hline affected by war & $\begin{array}{c}-0.0140 \\
(0.0413)\end{array}$ & $\begin{array}{c}-0.0145 \\
(0.0410)\end{array}$ & $\begin{array}{c}0.0105 \\
(0.0322)\end{array}$ \\
\hline \multicolumn{4}{|l|}{ perception of institutions } \\
\hline trust institutions & $\begin{array}{l}-0.0940^{* * *} \\
(0.0221)\end{array}$ & $\begin{array}{l}-0.0939^{* * *} \\
(0.0223)\end{array}$ & $\begin{array}{l}-0.0831^{* * *} \\
(0.0239)\end{array}$ \\
\hline effective institutions exist & $\begin{array}{l}-0.134^{* * *} \\
(0.0333)\end{array}$ & $\begin{array}{l}-0.134^{* * *} \\
(0.0332)\end{array}$ & $\begin{array}{l}-0.139^{* * *} \\
(0.0257)\end{array}$ \\
\hline political liberties exist & $\begin{array}{r}-0.0348 \\
(0.0297)\end{array}$ & $\begin{array}{r}-0.0347 \\
(0.0295)\end{array}$ & $\begin{array}{c}0.0210 \\
(0.0306)\end{array}$ \\
\hline corruption exists & $\begin{array}{c}0.00569 \\
(0.00420)\end{array}$ & $\begin{array}{c}0.00572 \\
(0.00420)\end{array}$ & $\begin{array}{c}0.00238 \\
(0.00206)\end{array}$ \\
\hline incomes should be more equal & $\begin{array}{c}-0.0300 \\
(0.0431)\end{array}$ & $\begin{array}{c}-0.0319 \\
(0.0435)\end{array}$ & $\begin{array}{l}-0.0676^{* *} \\
(0.0306)\end{array}$ \\
\hline \multicolumn{4}{|l|}{ social capital } \\
\hline meet up with friends & $\begin{array}{c}0.0375 \\
(0.0234)\end{array}$ & $\begin{array}{c}0.0375 \\
(0.0232)\end{array}$ & $\begin{array}{c}0.0217 \\
(0.0134)\end{array}$ \\
\hline member of a political party & $\begin{array}{c}-0.133^{*} \\
(0.0647)\end{array}$ & $\begin{array}{c}-0.133^{*} \\
(0.0645)\end{array}$ & $\begin{array}{r}-0.0921^{*} \\
(0.0538)\end{array}$ \\
\hline active member of organizations & $\begin{array}{c}0.00338 \\
(0.0249)\end{array}$ & $\begin{array}{c}0.00292 \\
(0.0249)\end{array}$ & $\begin{array}{c}0.0286^{*} \\
(0.0154)\end{array}$ \\
\hline Country dummies & $\checkmark$ & $\checkmark$ & $\checkmark$ \\
\hline Date of interview dummies & $\checkmark$ & $\checkmark$ & \\
\hline $\begin{array}{l}\text { Observations } \\
R^{2}\end{array}$ & $\begin{array}{l}4638 \\
0.0711\end{array}$ & $\begin{array}{l}4638 \\
0.0715\end{array}$ & $\begin{array}{l}11876 \\
0.0580\end{array}$ \\
\hline
\end{tabular}

Notes: Dependent variable is the nine-point difference between the second life satisfaction question and the first life satisfaction question. OLS - Coefficients are reported. Standard errors are clustered at the country level. Significance levels: * $p<0.1$, ** 350.05 , *** $p<0.01$.

Table A5: Interview duration and date of interview effects 


\begin{tabular}{|c|c|c|c|}
\hline & $\begin{array}{l}(1) \\
\text { five-point difference }\end{array}$ & $\begin{array}{l}(2) \\
\text { five-point difference }\end{array}$ & $\begin{array}{l}\text { (3) } \\
\text { five-point difference }\end{array}$ \\
\hline \multicolumn{4}{|l|}{$\underline{\text { baseline }}$} \\
\hline health & $\begin{array}{c}0.0137 \\
(0.00826)\end{array}$ & $\begin{array}{c}0.000602 \\
(0.00777)\end{array}$ & $\begin{array}{c}0.00199 \\
(0.00882)\end{array}$ \\
\hline married & $\begin{array}{r}-0.00517 \\
(0.0121)\end{array}$ & $\begin{array}{c}-0.0122 \\
(0.0122)\end{array}$ & $\begin{array}{c}-0.0111 \\
(0.0135)\end{array}$ \\
\hline Age $18-22$ & $\begin{array}{c}0.0192 \\
(0.0241)\end{array}$ & $\begin{array}{c}0.0232 \\
(0.0242)\end{array}$ & $\begin{array}{c}0.0139 \\
(0.0277)\end{array}$ \\
\hline Age $23-32$ & $\begin{array}{c}0.00494 \\
(0.0188)\end{array}$ & $\begin{array}{c}-0.00161 \\
(0.0201)\end{array}$ & $\begin{array}{c}-0.0162 \\
(0.0232)\end{array}$ \\
\hline Age $33-42$ & $\begin{array}{c}0.0137 \\
(0.0128)\end{array}$ & $\begin{array}{c}0.0161 \\
(0.0133)\end{array}$ & $\begin{array}{c}0.0135 \\
(0.0149)\end{array}$ \\
\hline Age 53-62 & $\begin{array}{r}-0.00737 \\
(0.0149)\end{array}$ & $\begin{array}{l}-0.000148 \\
(0.0156)\end{array}$ & $\begin{array}{c}0.00838 \\
(0.0179)\end{array}$ \\
\hline Age 63- & $\begin{array}{l}-0.0925^{* * *} \\
(0.0151)\end{array}$ & $\begin{array}{l}-0.0638^{* * *} \\
(0.0161)\end{array}$ & $\begin{array}{l}-0.0715^{* * *} \\
(0.0199)\end{array}$ \\
\hline \multicolumn{4}{|l|}{ individual SES } \\
\hline education & & $\begin{array}{l}0.0212^{* * *} \\
(0.00517)\end{array}$ & \\
\hline income & & $\begin{array}{r}0.0184^{* *} \\
(0.00708)\end{array}$ & \\
\hline employed & & $\begin{array}{c}0.0150 \\
(0.0153)\end{array}$ & \\
\hline \multicolumn{4}{|l|}{ parental background } \\
\hline father's education & & & $\begin{array}{l}0.0108^{* * *} \\
(0.00216)\end{array}$ \\
\hline affected by war & & & $\begin{array}{r}0.00411 \\
(0.0172)\end{array}$ \\
\hline Country dummies & $\checkmark$ & $\checkmark$ & $\checkmark$ \\
\hline $\begin{array}{l}\text { Observations } \\
R^{2}\end{array}$ & $\begin{array}{l}37795 \\
0.0465\end{array}$ & $\begin{array}{l}36261 \\
0.0499\end{array}$ & $\begin{array}{l}26044 \\
0.0522\end{array}$ \\
\hline
\end{tabular}

Table A6: Five-point difference 


\begin{tabular}{|c|c|c|c|}
\hline & $\begin{array}{l}(4) \\
\text { five-point difference }\end{array}$ & $\begin{array}{l}(5) \\
\text { five-point difference }\end{array}$ & $\begin{array}{l}(6) \\
\text { five-point difference }\end{array}$ \\
\hline \multicolumn{4}{|l|}{ baseline } \\
\hline health & $\begin{array}{l}0.0245^{* * *} \\
(0.00671)\end{array}$ & $\begin{array}{l}0.0134 \\
(0.00797)\end{array}$ & $\begin{array}{c}-0.0000496 \\
(0.00840)\end{array}$ \\
\hline married & $\begin{array}{c}0.00180 \\
(0.0107)\end{array}$ & $\begin{array}{r}-0.00561 \\
(0.0121)\end{array}$ & $\begin{array}{c}-0.0149 \\
(0.0140)\end{array}$ \\
\hline Age $18-22$ & $\begin{array}{c}0.0158 \\
(0.0248)\end{array}$ & $\begin{array}{c}0.0125 \\
(0.0241)\end{array}$ & $\begin{array}{c}0.00413 \\
(0.0365)\end{array}$ \\
\hline Age $23-32$ & $\begin{array}{l}0.000220 \\
(0.0200)\end{array}$ & $\begin{array}{l}0.000349 \\
(0.0186)\end{array}$ & $\begin{array}{c}-0.0119 \\
(0.0247)\end{array}$ \\
\hline Age $33-42$ & $\begin{array}{c}0.0148 \\
(0.0146)\end{array}$ & $\begin{array}{c}0.0143 \\
(0.0126)\end{array}$ & $\begin{array}{c}0.0227 \\
(0.0164)\end{array}$ \\
\hline Age $53-62$ & $\begin{array}{r}-0.00670 \\
(0.0181)\end{array}$ & $\begin{array}{r}-0.00900 \\
(0.0146)\end{array}$ & $\begin{array}{c}0.0160 \\
(0.0222)\end{array}$ \\
\hline Age 63- & $\begin{array}{l}-0.0724^{* * *} \\
(0.0192)\end{array}$ & $\begin{array}{l}-0.0932^{* * *} \\
(0.0158)\end{array}$ & $\begin{array}{c}-0.0258 \\
(0.0213)\end{array}$ \\
\hline \multicolumn{4}{|l|}{ individual SES } \\
\hline education & & & $\begin{array}{r}0.0135^{* *} \\
(0.00505)\end{array}$ \\
\hline income & & & $\begin{array}{c}0.0247^{* * *} \\
(0.00696)\end{array}$ \\
\hline employed & & & $\begin{array}{c}0.0138 \\
(0.0182)\end{array}$ \\
\hline \multicolumn{4}{|l|}{$\underline{\text { parental background }}$} \\
\hline father's education & & & $\begin{array}{l}0.00652^{* *} \\
(0.00244)\end{array}$ \\
\hline affected by war & & & $\begin{array}{c}0.0162 \\
(0.0183)\end{array}$ \\
\hline \multicolumn{4}{|l|}{ perception of institutions } \\
\hline trust institutions & $\begin{array}{l}-0.0604^{* * *} \\
(0.0106)\end{array}$ & & $\begin{array}{l}-0.0688^{* * *} \\
(0.0121)\end{array}$ \\
\hline effective institutions exist & $\begin{array}{l}-0.0744^{* * *} \\
(0.0155)\end{array}$ & & $\begin{array}{l}-0.0724^{* * *} \\
(0.0172)\end{array}$ \\
\hline political liberties exist & $\begin{array}{c}0.00992 \\
(0.0163)\end{array}$ & & $\begin{array}{c}0.0110 \\
(0.0187)\end{array}$ \\
\hline corruption exists & $\begin{array}{c}0.00186 \\
(0.00146)\end{array}$ & & $\begin{array}{c}0.00182 \\
(0.00152)\end{array}$ \\
\hline incomes should be more equal & $\begin{array}{l}-0.0579^{* * *} \\
(0.0174)\end{array}$ & & $\begin{array}{l}-0.0544^{* * *} \\
(0.0197)\end{array}$ \\
\hline \multicolumn{4}{|l|}{$\underline{\text { social capital }}$} \\
\hline meet up with friends & & $\begin{array}{c}0.00973 \\
(0.00599)\end{array}$ & $\begin{array}{c}0.0153^{*} \\
(0.00774)\end{array}$ \\
\hline member of a political party & & $\begin{array}{r}-0.0446^{*} \\
(0.0252)\end{array}$ & $\begin{array}{c}-0.0482 \\
(0.0350)\end{array}$ \\
\hline active member of organizations & & $\begin{array}{r}0.0172^{* *} \\
(0.00728)\end{array}$ & $\begin{array}{c}0.00602 \\
(0.00839)\end{array}$ \\
\hline Country dummies & $\checkmark$ & $\checkmark$ & $\checkmark$ \\
\hline Observations & 26945 & 37127 & 18938 \\
\hline$R^{2}$ & 0.0621 & 0.0469 & 0.0731 \\
\hline
\end{tabular}

Notes: Dependent variable is the five-point difference between the second life satisfaction question and the first life satisfaction question. OLS - Coefficients are reported. Standard errors are clustered at the country-administrative regional level. Significance levels: ${ }^{*} p<0.1,{ }^{* *} p<0.05,{ }^{* * *} p<0.01$.

Five-point difference (continued) 


\begin{tabular}{|c|c|c|c|}
\hline & $\begin{array}{c}(1) \\
\text { Nine-point diff, alt. coding }\end{array}$ & $\begin{array}{c}(2) \\
\text { Nine-point diff, alt. coding }\end{array}$ & $\begin{array}{c}(3) \\
\text { Nine-point diff, alt. coding }\end{array}$ \\
\hline \multicolumn{4}{|l|}{ Baseline } \\
\hline Health & $\begin{array}{l}0.0562^{* * *} \\
(0.0120)\end{array}$ & $\begin{array}{l}0.0314^{* *} \\
(0.0125)\end{array}$ & $\begin{array}{l}0.0387^{* * *} \\
(0.0127)\end{array}$ \\
\hline Married & $\begin{array}{c}0.0248^{*} \\
(0.0145)\end{array}$ & $\begin{array}{c}0.0106 \\
(0.0143)\end{array}$ & $\begin{array}{c}0.0202 \\
(0.0163)\end{array}$ \\
\hline Age 18-22 & $\begin{array}{c}0.0194 \\
(0.0323)\end{array}$ & $\begin{array}{c}0.0222 \\
(0.0342)\end{array}$ & $\begin{array}{r}0.00432 \\
(0.0394)\end{array}$ \\
\hline Age $23-32$ & $\begin{array}{c}-0.00364 \\
(0.0225)\end{array}$ & $\begin{array}{c}-0.0144 \\
(0.0243)\end{array}$ & $\begin{array}{c}-0.0421 \\
(0.0273)\end{array}$ \\
\hline Age $33-42$ & $\begin{array}{l}-0.000450 \\
(0.0157)\end{array}$ & $\begin{array}{c}0.00343 \\
(0.0161)\end{array}$ & $\begin{array}{c}-0.00834 \\
(0.0182)\end{array}$ \\
\hline Age $53-62$ & $\begin{array}{l}0.000337 \\
(0.0214)\end{array}$ & $\begin{array}{c}0.0143 \\
(0.0214)\end{array}$ & $\begin{array}{c}0.0174 \\
(0.0261)\end{array}$ \\
\hline Age 63- & $\begin{array}{l}-0.0997^{* * *} \\
(0.0210)\end{array}$ & $\begin{array}{l}-0.0597^{* * *} \\
(0.0209)\end{array}$ & $\begin{array}{c}-0.0596^{* *} \\
(0.0239)\end{array}$ \\
\hline \multicolumn{4}{|l|}{$\underline{\text { Individual SES }}$} \\
\hline Education & & $\begin{array}{l}0.0282^{* * *} \\
(0.00686)\end{array}$ & \\
\hline Income & & $\begin{array}{l}0.0435^{* * *} \\
(0.00875)\end{array}$ & \\
\hline Employed & & $\begin{array}{c}0.0182 \\
(0.0198)\end{array}$ & \\
\hline \multicolumn{4}{|l|}{$\underline{\text { Parental background }}$} \\
\hline Father's education & & & $\begin{array}{l}0.0157^{* * *} \\
(0.00318)\end{array}$ \\
\hline Affected by war & & & $\begin{array}{r}0.00121 \\
(0.0218)\end{array}$ \\
\hline Country dummies & $\checkmark$ & $\checkmark$ & $\checkmark$ \\
\hline $\begin{array}{l}\text { Observations } \\
R^{2}\end{array}$ & $\begin{array}{l}37795 \\
0.0440\end{array}$ & $\begin{array}{r}36261 \\
0.0504\end{array}$ & $\begin{array}{r}26044 \\
0.0483\end{array}$ \\
\hline
\end{tabular}

Notes: Dependent variable is the nine-point difference between the second life satisfaction question and the first life satisfaction question, assigning the 6 category in the second question to the "agree" category in the first question. OLS - Coefficients are reported. Standard errors are clustered at the country level. Significance levels: ${ }^{*} p<0.1,{ }^{* *} p<0.05,{ }^{* * *} p<0.01$.

Table A7: Alternative coding of nine-point difference 
Baseline

\begin{tabular}{|c|c|c|c|}
\hline Health & $\begin{array}{l}0.0677^{* * *} \\
(0.0109)\end{array}$ & $\begin{array}{l}0.0543^{* * *} \\
(0.0116)\end{array}$ & $\begin{array}{l}0.0307^{* *} \\
(0.0128)\end{array}$ \\
\hline Married & $\begin{array}{l}0.0310^{* *} \\
(0.0141)\end{array}$ & $\begin{array}{c}0.0251^{*} \\
(0.0147)\end{array}$ & $\begin{array}{c}0.0110 \\
(0.0165)\end{array}$ \\
\hline Age $18-22$ & $\begin{array}{c}0.0261 \\
(0.0323)\end{array}$ & $\begin{array}{c}0.00932 \\
(0.0317)\end{array}$ & $\begin{array}{c}-0.00124 \\
(0.0490)\end{array}$ \\
\hline Age 23-32 & $\begin{array}{r}-0.0125 \\
(0.0236)\end{array}$ & $\begin{array}{c}-0.00942 \\
(0.0222)\end{array}$ & $\begin{array}{c}-0.0381 \\
(0.0278)\end{array}$ \\
\hline Age $33-42$ & $\begin{array}{c}-0.00173 \\
(0.0179)\end{array}$ & $\begin{array}{c}-0.00108 \\
(0.0156)\end{array}$ & $\begin{array}{c}-0.00266 \\
(0.0191)\end{array}$ \\
\hline Age 53-62 & $\begin{array}{c}-0.00480 \\
(0.0236)\end{array}$ & $\begin{array}{r}-0.00247 \\
(0.0211)\end{array}$ & $\begin{array}{c}0.0267 \\
(0.0290)\end{array}$ \\
\hline Age 63- & $\begin{array}{c}-0.0697^{* *} \\
(0.0275)\end{array}$ & $\begin{array}{c}-0.0976^{* * *} \\
(0.0215)\end{array}$ & $\begin{array}{c}0.00196 \\
(0.0242)\end{array}$ \\
\hline
\end{tabular}

$\underline{\text { Individual SES }}$

Education

0.0118

$(0.00698)$

Income

$0.0439^{* * *}$

(0.00992)

Employed

0.0163

(0.0216)

Parental background

Father's education

$0.0101^{* * *}$

(0.00340)

Affected by war

0.0150

(0.0251)

Perception of institutions

Trust institutions

Effective institutions exist

Political liberties exist

Corruption exists

Incomes should be more equal

$\underline{\text { Social capital }}$

Meet up with friends

Member of a political party

Active member of organizations

$$
\begin{gathered}
-0.0604^{* * *} \\
(0.0149) \\
-0.102^{* * *} \\
(0.0186) \\
0.0169 \\
(0.0210) \\
0.00256 \\
(0.00232) \\
-0.0831^{* * *} \\
(0.0204)
\end{gathered}
$$

$-0.0788^{* * *}$

(0.0164)

$-0.0983^{* * *}$

(0.0206)

0.0205

$(0.0245)$

0.00204

(0.00225)

$-0.0721^{* * *}$

(0.0211)

Country dummies

$\begin{array}{cc}0.0198^{* *} & 0.0283^{* *} \\ (0.00837) & (0.0107) \\ -0.0560 & -0.0817^{*} \\ (0.0348) & (0.0429) \\ 0.0175^{*} & 0.00659 \\ (0.00864) & (0.0114)\end{array}$

Observations

ies $\checkmark \checkmark$

$R^{2}$

0.0558

$\checkmark$

37127

18938

0.0446

0.0673

Notes: Dependent variable is the nine-point difference between the second life satisfaction question and the first life satisfaction question, assigning the 6 category in the second question to the "agree" category in the first question. OLS Coefficients are reported. Standard errors are clustered at the country level. Significance levels: ${ }^{*} p<0.1,{ }^{* *} p<0.05$, $* * * p<0.01$. 


\section{Additional Data Information}

Dependent variables: See description in text.

\section{Baseline}

Health Captures the respondent's self-reported health on a scale of 1 (very bad) to 5 (very good); LiTS 2010 q.704.

Married Dummy variable for whether the respondent is married; LiTS 2010 q.701.

Age dummies: Include the following categories: 23-32; 33-42; 43-52; 53-62; and 63 and above; LiTS 2010 q.104.

\section{Individual SES}

Education: Education of the respondent, on a scale of 1 (no education) to 6 (Master's/Ph-D); LiTS 2010 q.515.

Income: Income of the respondent's household, as measured on a 10-step income ladder; LiTS 2010 q.330.

Employed: Dummy variable for employment in the past 12 months; LiTS 2010 q.501.

\section{Parental background}

Father's education: Years of respondent's father's full-time education; LiTS 2010 q.718.

Affected by war: Dummy for whether the respondent, or any of his parents or grandparents were killed, injured or forced to move during World War II; LiTS 2010 q.721.

\section{Perceptions of institutions}

Corruption: The degree to which the respondent believes that people like him have to make unofficial payments or gifts when using a range of public services (such as interacting with 
the road police or going to courts for a civil matter), where 1 is never and 5 is always; LiTS 2010 q.601.

Trust institutions: The degree to which the respondent trusts a list of institutions and outcomes, such as Parliament, courts, or foreign investors, on a scale of 1 (complete distrust) to 5 (complete trust); LiTS 2010 q.303.

Effective institutions: The degree to which the respondent believes that a list of institutions and outcomes, such as law and order and freedom of speech, exist in his country (on a scale of 1 (completely disagree) to 5 (completely agree)); LiTS 2010 q.312.

Income equality: Dummy variable for whether the respondent supports income equality; LiTS 2010 q.316.

\section{Social capital}

Meet up with friends: The extent to which the respondent meets up with friends, on a scale of 1 (never) to 5 (on most days); LiTS 2010 q.325.

Member of a political party: Dummy variable for whether the respondent is a member of a political party; LiTS 2010 q.712.

Active member of organisations: The number of voluntary organisations, such as labour unions and youth associations, of which the respondent is an active member; LiTS 2010 q.713. 